\title{
The Cradle of Gordon Life Science Institute and its Development and Driving Force
}

\author{
Kuo Chen $\mathrm{Chou}^{* 1,2}$ \\ ${ }^{1}$ Gordon Life Science Institute, USA \\ ${ }^{2}$ Center for Informational Biology, University of Electronic Science and Technology of China, China
}

*Corresponding author: Kuo Chen Chou, Gordon Life Science Institute, USA and Center for Informational Biology, University of

Electronic Science and Technology of China, China

\section{ARTICLE INFO}

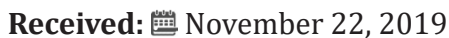

Published: 㓞 December 17, 2019

Citation: Kuo Chen Chou. The Cradle of Gordon Life Science Institute and its Development and Driving Force. Biomed J Sci \& Tech Res 23(5)-2019. BJSTR. MS.ID.003978.

\begin{abstract}
Gordon Life Science Institute is the first Internet Research Institute ever established in the world. It is a non-profit institute. Those scientists who are really dedicated themselves to science and loving science more than anything else can become its member. In the friendly door-opened Institute, they can maximize their time and energy to engage in their scientific creativity. They have also believed that science would be more truthful and wonderful if scientists do not have to spend a lot of time on funding application, and that great scientific findings and creations in history were often made by those who were least supported or funded but driven by interesting imagination and curiosity. Recollected in this minireview is its establishing and developing processes, as well as its philosophy and accomplishments.
\end{abstract}

Keywords: Reform and Opening; Free Communication; Sweden; Cradle; San Diego; Boston; Door-Opening

\section{Short Communication}

The Gordon Life Science Institute was established in 2003 at San Diego of California, USA. Its founder is Professor Dr. Kuo-Chen Chou. Its mission is to develop and apply new mathematical tools and physical concepts for understanding biological phenomena. For more detailed about the growth process of Gordon Life Science Institute as well as its novel philosophy, see an article at

https://gordonlifescience.org/GordonLifeScience.html.

The Gordon Life Science Institute is a newly emerging academic organization in the Age of Information and Internet. Founded by Professor Dr. Kuo-Chen Chou at San Diego of California, right after he was retired from Pfizer Global Research and Development in 2003. Its mission is to develop and apply new mathematical tools and physical concepts for understanding biological phenomena. The Institute's name reflects an interesting historical story. After the Cultural Revolution, China started to open its door, the founder was invited by Professor Sture Forsén, the then Chairman of Nobel Prize Committee, to work in Chemical Center of Lund University as a
Visiting Professor. To make Swedish people easier to pronounce his name, Professor Chou used "Gordon" as his name in Sweden. About a quarter of century later, the same name was used for the Institute, meaning that "Reform and Opening" and "Free Communication" can stimulate a lot of great creativities. The current liaison site of Gordon Life Science Institute is in Boston of Massachusetts, USA; gls@gordonlifescience.org.

\section{Mission and Organization}

The Institute has no physical boundaries. Its members do not have to work in a same building or campus. Distributed over different countries of the world, they shall freely collaborate, exchange ideas, and share information and findings via a variety of modern communication methods. This versatile system allows the members to focus completely on science without having to cope with troubles in obtaining visas and in paying for relocation expenses, among many others. The Gordon Life Science Institute is a non-profit organization. It is a gift to science and human beings. Its founding principle is to pursue the excellence in science: anyone 
who has proved his/her creativity in science can become a member regardless of his/her age, occupation, and nationality. Accordingly, the Institute has provided an ideal society or organization for those scientists who are really dedicated themselves to science and loving science more than anything else. In the friendly door-opened Institute, these scientists can maximize their time and energy to engage in their scientific creativity. Members of the Institute believe science would be more truthful and wonderful if scientists do not have to spend a lot of time on funding application. We also note that great scientific findings and creations in history were often made by those who were least supported or funded but driven by intriguing imagination and awesome curiosity.

\section{Accomplishments}

Up to March 2019, the Institute has 26 members. Among them 5 have been selected by Thompson Reuter and Clarivate Analytics as the "Highly Cited Researcher":

(1) Kuo-Chen Chou for continuously 5 years $(2014,2015$, 2016, 2017, and 2018),

(2) Hong-Bin Shen (2014 and 2015),

(3) Wei Chen (2018),

(4) Hao Lin (2018), and

(5) Xoan Xiao (2018).

Listed below are just some represented works produced by the Gordon Life Science Institute.

\section{Extension of Special PseAAC to the General One}

With the explosive growth of biological sequences in the postgenomic era, one of the most challenging problems in computational biology is how to express a biological sequence with a discrete model or a vector, yet still keep considerable sequence-order information or key pattern characteristic. This is because all the existing machine-learning algorithms (such as "Optimization" algorithm [1], "Covariance Discriminant" or "CD" algorithm [2,3], "Nearest Neighbor" or "NN" algorithm [4], and "Support Vector Machine" or "SVM" algorithm [4,5]) can only handle vectors as elaborated in a comprehensive review [6]. However, a vector defined in a discrete model may completely lose all the sequence-pattern information. To avoid completely losing the sequence-pattern information for proteins, the pseudo amino acid composition [7] or PseAAC [8] was proposed.

Ever since then, it has been widely used in nearly all the areas of computational proteomics [3,9-266]. Because it has been widely and increasingly used, four powerful open access soft-wares, called 'PseAAC' [267], 'PseAAC-Builder' [268], 'propy' [269], and 'PseAAC-General' [270], were established: the former three are for generating various modes of Chou's special PseAAC [271]; while the 4th one for those of Chou's general PseAAC [272], including not only all the special modes of feature vectors for proteins but also the higher level feature vectors such as "Functional Domain" mode (see Eqs.9-10 of [272]), "Gene Ontology” mode (see Eqs.11-12 of [272]), and "Sequential Evolution" or "PSSM" mode (see Eqs.1314 of [272]). For more information about the PseAAC, please visit an insightful Wikipedia article at https://en.wikipedia.org/wiki/ Pseudo_amino_acid_composition.

\section{Extension of PseAAC to PseKNC}

Encouraged by the successes of using PseAAC to deal with protein/peptide sequences, the concept of PseKNC (Pseudo K-tuple Nucleotide Composition) [273] was developed for generating various feature vectors for DNA/RNA sequences that have proved very useful as well [273-290]. Particularly, in 2015 a very powerful web-server called 'Pse-in-One' [291] and its updated version 'Pse-in-One2.0' [292] have been established that can be used to generate any desired feature vectors for protein/peptide and DNA/RNA sequences according to the need of users' studies". For more information about the PseKNC, please visit an insightful Wikipedia article at https://en.wikipedia.org/wiki/Pseudo_Ktuple_nucleotide_composition.

\section{Distorted Key Theory for Peptide Drugs}

According to Fisher's "lock and key" model [293], Koshland's "induced fit" theory [293], and the "rack mechanism" [294], the prerequisite condition for a peptide to be cleaved by the diseasecausing enzyme is a good fit and tightly binding with the enzyme's active site (Figure1). However, such a peptide, after a modification on its scissile bond with some simple chemical procedure, will no longer be cleavable by the enzyme but it can still tightly bind to its active site. A schematic illustration about the distorted key theory is given in Figure 2, where panel

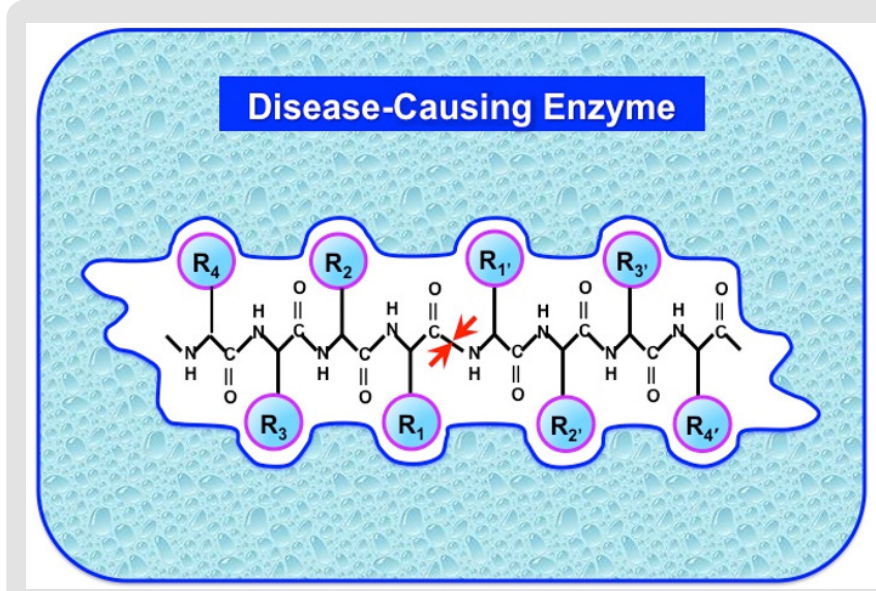

Figure 1: A schematic illustration to show a peptide in good fitting and tightly binding with the enzyme's active site before it is cleaved by the latter. Adapted from [296] with permission.

(a) Shows an effective binding of a cleavable peptide to the active site of HIV protease, while panel

(b) The peptide has become a non-cleavable one after its scissile bond is modified although it can still tightly bind to the active site. 
a

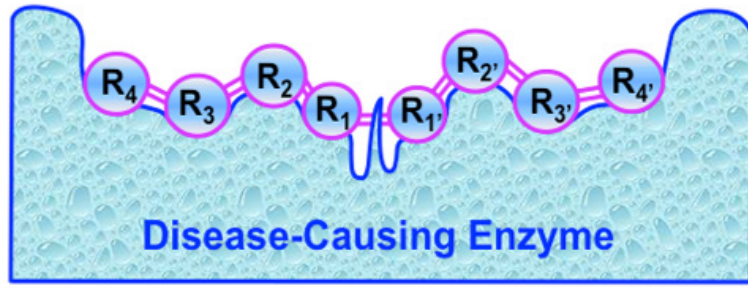

b

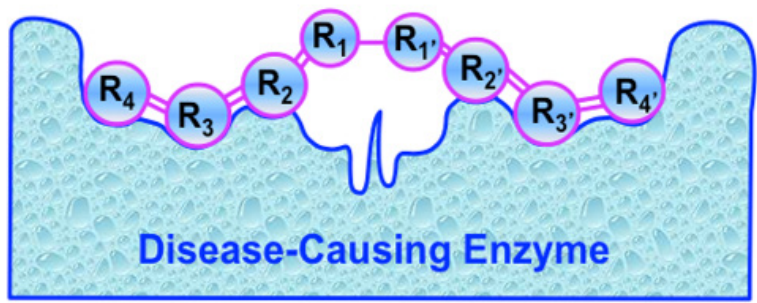

Figure 2: Schematic drawing to illustrate the "Distorted Key" theory, where panel

(a) Shows an effective binding of a cleavable peptide to the active site of a disease-causing enzyme, while panel

(b) The same peptide has become a non-cleavable one after its scissile bond is modified although it can still bind to the active site. Such a modified peptide, or "distorted key", will automatically become an inhibitor candidate against the disease-causing enzyme. Adapted from [296] with permission.

Such a modified peptide, or "distorted key", will automatically become an inhibitor candidate against HIV protease. Even for nonpeptide inhibitors, the information derived from the cleavable peptides can also provide useful insights about the key binding groups and fitting conformation in the sense of microenvironment. Besides, peptide drugs usually have no toxicity in vivo under the physiological concentration [295]. For more discussion about the distorted key theory, see a comprehensive review paper [296]. It was based on such a distorted key theory that many investigators were enthusiastic to develop various methods for predicting the protein cleavage sites by disease-causing enzymes (see, e.g., [295, 297-302]). Furthermore, a webserver called "HIVcleave" [299] has been established for predicting HIV protease cleavage sites in proteins. Its website address is at http://chou.med.harvard.edu/ bioinf/HIV/. For more discussions about the "distorted key theory", see an insightful Wikipedia article at https://en.wikipedia.org/ wiki/Chou\%27s_distorted_key_theory_for_peptide_drugs.

\section{Introduction of Wenxiang Diagram}

Using graphic approaches to study biological and medical systems can provide an intuitive vision and useful insights for helping analyze complicated relations therein, as indicated by many previous studies on a series of important biological topics, (see, e.g., [303]). Its importance can also be seen in an insightful Wikipedia article at https://en.wikipedia.org/wiki/Graph_theory_ in_enzymatic_kinetics. The wenxiang diagram [304] is a special kind of graphical approach, which is very useful for in-depth studying protein-protein interaction mechanism [305,306]. For more about the wenxiang diagram, see an insightful Wikipedia article at https://en.wikipedia.org/wiki/Wenxiang_diagram.

\section{Predictors for Multi-Label Systems}

Information of subcellular localization for a protein is indispensable for revealing its biological function. Therefore, one of the fundamental goals in molecular cell biology and proteomics is to determine the subcellular locations of proteins in an entire cell. Before 2007, most efforts in this regard were focused on the single-label system by assuming that each of the constitute proteins in a cell had one, and only one, subcellular location (see, e.g., [307-311]). However, with more experimental data uncovered, it has been found that many proteins may simultaneously occur or move between two or more location sites in a cell and hence need multiple labels to mark them. Proteins with multiple locations are also called multiplex proteins [312,313], which are often the special targets for drug development [313-319]). Therefore, how to deal with this kind of multi-label systems is a critical challenge. To take the challenge, the Institute has developed the following four series of predictors:

(1) PLoc [313,320-326];

(2) iLoc [327-332];

(3) pLoc-m [203,204,215,224-226,333];

(4) pLoc_bal $[227-230,254,265,266]$.

All these predictors have yielded very high success rates, both globally and locally, as summarized in a comprehensive review paper [334]. For more about protein subcellular localization prediction, see an insightful Wikipedia article at https://en.wikipedia.org/ wiki/Protein_subcellular_localization_prediction.

\section{Five-Steps Rule}

The Institute was the birthplace of the famous 5-steps rule [272], which has been used in nearly all the areas of computational biology [203-204,215,224-230,233,251,254-256,259-261,264$265,277,279,288,333-368])$, material science [369], and even the commercial science (e.g., the bank account systems). The only difference between the them is how to formulate the statistical samples or events with an effective mathematical expression that can truly reflect their intrinsic correlation with the target to be predicted. Like the case of many machine-learning algorithms, the " 5 -steps rule" can be widely used in nearly all the areas of statistical analysis. For more about the 5-steps rule, see an insightful Wikipedia article at https://en.wikipedia.org/wiki/5-step_rules. Working in such Institute filled with this kind of philosophy and atmosphere, the scientists would be more prone to be stimulated by the eight pioneering papers from the then Chairman of Nobel Prize Committee Sture Forsen [370-377] and many of their follow-up papers $[172,189,305,348,378-425]$, so as to drive them substantially more creative and productive. 


\section{Conclusion and Perspective}

In comparison with the conventional institutes, Gordon Life Science Institute has the following unique advantages: it can

(1) Attract those scientists who are really loving science more than anything else;

(2) Maximize their creativity in science and minimize the distraction or disturbance caused by the relocation and various followed-up tedious things;

(3) Provide them with an ideal environment to completely focus on doing science;

(4) Drive their motivation by insightful imagination and intriguing curiosity; and

(5) Create the atmosphere to guide their scientific results more truthful and wonderful.

Accordingly, it would not be surprised to see that a total of five members of Gordon Life Scientist have been selected by Clarivate Analytics as Highly Cited Researcher or HCR (https://hcr.clarivate. com/resources/archived-lists/), indicating that for the ratio of HCR per member, the "Gordon Life Science Institute" has already exceeded the "Broad Institute of MIT and Harvard, USA", becoming the top in the world. For more remarkable and awesome role of the Institute in stimulating the development of computational biology and drug development, see [334,348,418-420,423-424,426-427], where a series of insightful recollections at different angles or from various aspects have been very impressively presented. It is expected that more significant accomplishments will be achieved by the Gordon Life Science Institute for many years to come.

\section{References}

1. CT Zhang, KC Chou (1992) An optimization approach to predicting protein structural class from amino acid composition. Protein Science 1(3): 401-408.

2. KC Chou, DW Elrod (2002) Bioinformatical analysis of G-protein-coupled receptors. Journal of Proteome Research 1(5): 429-433.

3. KC Chou, YD Cai (2003) Prediction and classification of protein subcellular location: sequence-order effect and pseudo amino acid composition. Journal of Cellular Biochemistry 90(6): 1250-1260.

4. L Hu, T Huang, X Shi, WC Lu, YD Cai, et al. (2011) Predicting functions of proteins in mouse based on weighted protein-protein interaction network and protein hybrid properties. PLoS ONE 6: e14556.

5. YD Cai, KY Feng, WC Lu, KC Chou (2006) Using LogitBoost classifier to predict protein structural classes. Journal of Theoretical Biology 238(1): 172-176.

6. KC Chou (2015) Impacts of bioinformatics to medicinal chemistry. Medicinal Chemistry 11(3): 218-234.

7. KC Chou (2001) Prediction of protein cellular attributes using pseudo amino acid composition. PROTEINS: Structure, Function, and Genetics 43(3): 246-255.

8. KC Chou (2005) Using amphiphilic pseudo amino acid composition to predict enzyme subfamily classes. Bioinformatics 21(1): 10-19.

9. ZM Guo (2002) Prediction of membrane protein types by using pattern recognition method based on pseudo amino acid composition. Master
Thesis, Bio-X Life Science Research Center, Shanghai. Natural Science $9(4)$.

10. KC Chou, YD Cai (2003) Predicting protein quaternary structure by pseudo amino acid composition. PROTEINS: Structure, Function, and Genetics 53(2): 282-289.

11. Pan YX, Zhang ZZ, Guo ZM, Feng GY, Huang ZD, et al. (2003) Application of pseudo amino acid composition for predicting protein subcellular location: stochastic signal processing approach. Journal of Protein Chemistry 22(4): 395-402.

12. Chou KC, Cai YD (2004) Predicting subcellular localization of proteins by hybridizing functional domain composition and pseudo amino acid composition. Journal of Cellular Biochemistry 91(6): 1197-1203.

13. M Wang, J Yang, GP Liu, ZJ Xu, KC Chou (2004) Weighted-support vector machines for predicting membrane protein types based on pseudo amino acid composition. Protein Engineering, Design, and Selection 17(6): 509-516.

14. YD Cai, KC Chou (2005) Predicting enzyme subclass by functional domain composition and pseudo amino acid composition. Journal of Proteome Research 4(3): 967-971.

15. YD Cai, GP Zhou, KC Chou (2005) Predicting enzyme family classes by hybridizing gene product composition and pseudo amino acid composition. Journal of Theoretical Biology 234(1): 145-149.

16. Gao Y, Shao S, Xiao X, Ding Y, Huang Y, et al. (2005) Using pseudo amino acid composition to predict protein subcellular location: approached with Lyapunov index, Bessel function, and Chebyshev filter. Amino Acids 28(4): 373-376.

17. Liu H, Yang J, Wang M, Xue L, Chou KC (2005) Using Fourier spectrum analysis and pseudo amino acid composition for prediction of membrane protein types. The Protein Journal 24(6): 385-389.

18. Shen H, Chou KC (2005) Using optimized evidence-theoretic K-nearest neighbor classifier and pseudo amino acid composition to predict membrane protein types. Biochemical \& Biophysical Research Communications (BBRC) 334(1): 288-292.

19. Shen H, Chou KC (2005) Predicting protein subnuclear location with optimized evidence-theoretic K-nearest classifier and pseudo amino acid composition. Biochem Biophys Res Comm (BBRC) 337: 752-756.

20. Cai YD, Chou KC (2006) Predicting membrane protein type by functional domain composition and pseudo amino acid composition. Journal of Theoretical Biology 238(2): 395-400.

21. C Chen, YX Tian, XY Zou, PX Cai, JY Mo (2006) Using pseudo amino acid composition and support vector machine to predict protein structural class. J Theor Biol 243: 444-448.

22. Chen C, Zhou X, Tian Y, Zou X, Cai P (2006) Predicting protein structural class with pseudo amino acid composition and support vector machine fusion network. Analytical Biochemistry 357(1): 116-121.

23. P Du, Y Li (2006) Prediction of protein submitochondria locations by hybridizing pseudo amino acid composition with various physicochemical features of segmented sequence. BMC Bioinformatics 7: 518.

24. Mondal S, Bhavna R, Mohan Babu R, Ramakumar S (2006) Pseudo amino acid composition and multi-class support vector machines approach for conotoxin superfamily classification. J Theor Biol 243(2): 252-260.

25. HB Shen, J Yang, KC Chou (2006) Fuzzy KNN for predicting membrane protein types from pseudo amino acid composition. Journal of Theoretical Biology 240(1): 9-13.

26. SQ Wang, J Yang, KC Chou (2006) Using stacked generalization to predict membrane protein types based on pseudo amino acid composition. Journal of Theoretical Biology 242(4): 941-946.

27.X Xiao, SH Shao, YS Ding, ZD Huang, KC Chou (2006) Using cellular automata images and pseudo amino acid composition to predict protein subcellular location. Amino Acids 30(1): 49-54. 
28. X Xiao, SH Shao, ZD Huang, KC Chou (2006) Using pseudo amino acid composition to predict protein structural classes: approached with complexity measure factor. Journal of Computational Chemistry 27(4): 478-482.

29. Zhang SW, Pan Q, Zhang HC, Shao ZC, Shi JY (2006) Prediction protein homo-oligomer types by pseudo amino acid composition: Approached with an improved feature extraction and naive Bayes feature fusion. Amino Acids 30(4): 461-468.

30. GP Zhou, YD Cai (2006) Predicting protease types by hybridizing gene ontology and pseudo amino acid composition. PROTEINS: Structure, Function, and Bioinformatics 63(3): 681-684.

31. YL Chen, QZ Li (2007) Prediction of apoptosis protein subcellular location using improved hybrid approach and pseudo amino acid composition. Journal of Theoretical Biology 248(2): 377-381.

32. Ding YS, Zhang TL, Chou KC (2007) Prediction of protein structure classes with pseudo amino acid composition and fuzzy support vector machine network. Protein \& Peptide Letters 14(8): 811-815.

33. H Lin, QZ Li (2007) Predicting conotoxin superfamily and family by using pseudo amino acid composition and modified Mahalanobis discriminant. Biochem Biophys Res Commun 354(2): 548-551.

34. H Lin, QZ Li (2007) Using Pseudo Amino Acid Composition to Predict Protein Structural Class: Approached by Incorporating 400 Dipeptide Components. Journal of Computational Chemistry 28(9): 1463-1466.

35. P Mundra, M Kumar, KK Kumar, VK Jayaraman, BD Kulkarni (2007) Using pseudo amino acid composition to predict protein subnuclear localization: Approached with PSSM. Pattern Recognition Letters 28(13): 1610-1615.

36. JY Shi, SW Zhang, Q Pan, YM Cheng, J Xie (2007) Prediction of protein subcellular localization by support vector machines using multi-scale energy and pseudo amino acid composition. Amino Acids 33(1): 69-74.

37. Zhang TL, Ding YS (2007) Using pseudo amino acid composition and binary-tree support vector machines to predict protein structural classes. Amino Acids 33(4): 623-629.

38. Zhou XB, Chen C, Li ZC, Zou XY (2007) Using Chou's amphiphilic pseudo amino acid composition and support vector machine for prediction of enzyme subfamily classes. Journal of Theoretical Biology 248(3): 546551.

39. Diao Y, Ma D, Wen Z, Yin J, Xiang J, et al. (2008) Using pseudo amino acid composition to predict transmembrane regions in protein: cellular automata and Lempel-Ziv complexity. Amino Acids 34(1): 111-117.

40. YS Ding, TL Zhang (2008) Using Chou's pseudo amino acid composition to predict subcellular localization of apoptosis proteins: an approach with immune genetic algorithm-based ensemble classifier. Pattern Recognition Letters 29(13): 1887-1892.

41. Y Fang, Y Guo, Y Feng, M Li (2008) Predicting DNA-binding proteins: approached from Chou's pseudo amino acid composition and other specific sequence features. Amino Acids 34(1): 103-109.

42. Q Gu, Y Ding, T Zhang (2008) Prediction of G-protein-coupled receptor classes with pseudo amino acid composition. IEEE Xplore (iCBBE, Shanghai, China).

43. Jiang X, Wei R, Zhang T, Gu Q (2008) Using the concept of Chou's pseudo amino acid composition to predict apoptosis proteins subcellular location: an approach by approximate entropy. Protein \& Peptide Letters 15(4): 392-396.

44. X Jiang, R Wei, Y Zhao, T Zhang (2008) Using Chou's pseudo amino acid composition based on approximate entropy and an ensemble of AdaBoost classifiers to predict protein subnuclear location. Amino Acids 34(4): 669-675.

45. Li FM, Li QZ (2008) Using pseudo amino acid composition to predict protein subnuclear location with improved hybrid approach. Amino Acids 34(1): 119-125.
46. Li FM, Li QZ (2008) Predicting protein subcellular location using Chou's pseudo amino acid composition and improved hybrid approach. Protein \& Peptide Letters 15(6): 612-616.

47. H Lin (2008) The modified Mahalanobis discriminant for predicting outer membrane proteins by using Chou's pseudo amino acid composition. Journal of Theoretical Biology 252(2): 350-356.

48. Lin H, Ding H, Guo FB, Zhang AY, Huang J (2008) Predicting subcellular localization of mycobacterial proteins by using Chou's pseudo amino acid composition. Protein \& Peptide Letters 15(7): 739-744.

49. JY Shi, SW Zhang, Q Pan, GP Zhou (2008) Using Pseudo Amino Acid Composition to Predict Protein Subcellular Location: Approached with Amino Acid Composition Distribution. Amino Acids 35(2): 321-327.

50.Xiao X, Lin WZ, Chou KC (2008) Using grey dynamic modeling and pseudo amino acid composition to predict protein structural classes. Journal of Computational Chemistry 29(12): 2018-2024.

51.X Xiao, P Wang, KC Chou (2008) Predicting protein structural classes with pseudo amino acid composition: an approach using geometric moments of cellular automaton image. Journal of Theoretical Biology 254(7): 691-696

52. GY Zhang, BS Fang (2008) Predicting the cofactors of oxidoreductases based on amino acid composition distribution and Chou's amphiphilic pseudo amino acid composition. Journal of Theoretical Biology 253(2): 310-315.

53. Zhang GY, Li HC, Gao JQ Fang BS (2008) Predicting lipase types by improved Chou's pseudo amino acid composition. Protein \& Peptide Letters 15(10): 1132-1137.

54. Zhang SW, Chen W, Yang F, Pan Q (2008) Using Chou's pseudo amino acid composition to predict protein quaternary structure: a sequence segmented PseAAC approach. Amino Acids 35(3): 591-598.

55. Zhang SW, Zhang YL, Yang HF, Zhao CH, Pan Q (2008) Using the concept of Chou's pseudo amino acid composition to predict protein subcellular localization: an approach by incorporating evolutionary information and von Neumann entropies. Amino Acids 34(4): 565-572.

56. Zhang TL, Ding YS, Chou KC (2008) Prediction protein structural classes with pseudo amino acid composition: approximate entropy and hydrophobicity pattern. Journal of Theoretical Biology 250(1): 186-193.

57. Chen C, Chen L, Zou X, Cai P (2009) Prediction of protein secondary structure content by using the concept of Chou's pseudo amino acid composition and support vector machine. Protein \& Peptide Letters 16(1): 27-31.

58. Ding H, Luo L, Lin H (2009) Prediction of cell wall lytic enzymes using Chou's amphiphilic pseudo amino acid composition. Protein \& Peptide Letters 16(4): 351-355.

59. Du P, Cao S, Li Y (2009) SubChlo: predicting protein subchloroplast locations with pseudo amino acid composition and the evidencetheoretic K-nearest neighbor (ET-KNN) algorithm. Journal of Theoretical Biology 261(2): 330-335.

60. Gao QB, Jin ZC, Ye XF, Wu C, He J (2009) Prediction of nuclear receptors with optimal pseudo amino acid composition. Analytical Biochemistry 387(1): 54-59.

61. Georgiou DN, Karakasidis TE, Nieto JJ, Torres A (2009) Use of fuzzy clustering technique and matrices to classify amino acids and its impact to Chou's pseudo amino acid composition. Journal of Theoretical Biology 257(1): 17-26.

62. Li ZC, Zhou XB, Dai Z, Zou XY (2009) Prediction of protein structural classes by Chou's pseudo amino acid composition: approached using continuous wavelet transform and principal component analysis. Amino Acids 37(2): 415-425.

63. Lin H, Wang H, Ding H, Chen YL, Li QZ (2009) Prediction of Subcellular Localization of Apoptosis Protein Using Chou's Pseudo Amino Acid Composition. Acta Biotheoretica 57(3): 321-330. 
64. Qiu JD, Huang JH, Liang RP, Lu XQ (2009) Prediction of G-protein-coupled receptor classes based on the concept of Chou's pseudo amino acid composition: an approach from discrete wavelet transform. Analytical Biochemistry 390(1): 68-73.

65. X Xiao, P Wang, KC Chou (2009) Predicting protein quaternary structural attribute by hybridizing functional domain composition and pseudo amino acid composition. Journal of Applied Crystallography 42: 169173.

66. Zeng YH, Guo YZ, Xiao RQ, Yang L, Yu LZ, et al. (2009) Using the augmented Chou's pseudo amino acid composition for predicting protein submitochondria locations based on auto covariance approach Journal of Theoretical Biology 259(2): 366-372.

67. Esmaeili M, Mohabatkar H, Mohsenzadeh S (2010) Using the concept of Chou's pseudo amino acid composition for risk type prediction of human papillomaviruses. Journal of Theoretical Biology 263(2): 203-209.

68. Gao QB, Ye XF, Jin ZC, He J (2010) Improving discrimination of outer membrane proteins by fusing different forms of pseudo amino acid composition. Analytical Biochemistry 398(1): 52-59.

69. Q Gu, Y Ding, T Zhang, Y Shen (2010) Prediction of G-protein-coupled receptor classes with pseudo amino acid composition. Journal of Biomedical Engineering 27(3): 500-504.

70. Gu Q Ding YS, Zhang TL (2010) Prediction of G-Protein-Coupled Receptor Classes in Low Homology Using Chou's Pseudo Amino Acid Composition with Approximate Entropy and Hydrophobicity Patterns. Protein \& Peptide Letters 17(5): 559-567.

71. Kandaswamy KK, Pugalenthi G, Möller S, Hartmann E, Kalies KU (2010) Prediction of Apoptosis Protein Locations with Genetic Algorithms and Support Vector Machines Through a New Mode of Pseudo Amino Acid Composition. Protein and Peptide Letters 17(12): 1473-1479.

72. Liu T, Zheng X, Wang C, Wang J (2010) Prediction of Subcellular Location of Apoptosis Proteins using Pseudo Amino Acid Composition: An Approach from Auto Covariance Transformation. Protein \& Peptide Letters 17(10): 1263-1269.

73. H Mohabatkar (2010) Prediction of cyclin proteins using Chou's pseudo amino acid composition. Protein \& Peptide Letters 17(10): 1207-1214.

74. L Nanni, S Brahnam, A Lumini (2010) High performance set of PseAAC and sequence based descriptors for protein classification. Journal of Theoretical Biology 266(1): 1-10.

75. Xiaohui N, Nana L, Feng S, Xuehai H, Jingbo X, et al. (2010) Predicting protein solubility with a hybrid approach by pseudo amino Acid composition. Protein and Peptide Letters 17(12): 1466-1472.

76. Qiu JD, Huang JH, Shi SP, Liang RP (2010) Using the concept of Chou's pseudo amino acid composition to predict enzyme family classes: an approach with support vector machine based on discrete wavelet transform. Protein \& Peptide Letters 17(6): 715-722.

77. SS Sahu, G Panda (2010) A novel feature representation method based on Chou's pseudo amino acid composition for protein structural class prediction. Computational Biology and Chemistry 34(5-6): 320-327.

78. Wang YC, Wang XB, Yang ZX, Deng NY (2010) Prediction of enzyme subfamily class via pseudo amino acid composition by incorporating the conjoint triad feature. Protein \& Peptide Letters 17(11): 1441-1449.

79. J Wu, ML Li, LZ Yu, C Wang (2010) An ensemble classifier of support vector machines used to predict protein structural classes by fusing auto covariance and pseudo amino acid composition. Protein J 29(1): 62-67.

80. Yu L, Guo Y, Li Y, Li G, Li M, et al. (2010) SecretP: Identifying bacterial secreted proteins by fusing new features into Chou's pseudo amino acid composition. Journal of Theoretical Biology 267(1): 1-6.

81. Ding H, Liu L, Guo FB, Huang J, Lin H (2011) Identify Golgi protein types with modified mahalanobis discriminant algorithm and pseudo amino acid composition. Protein \& Peptide Letters 18(1): 58-63.
82. Guo J, Rao N, Liu G, Yang Y, Wang G (2011) Predicting protein folding rates using the concept of Chou's pseudo amino acid composition. Journal of Computational Chemistry 32(8): 1612-1617.

83. M Hayat, A Khan (2011) Predicting membrane protein types by fusing composite protein sequence features into pseudo amino acid composition. Journal of Theoretical Biology 271(1): 10-17.

84. Hu L, Zheng L, Wang Z, Li B, Liu L (2011) Using pseudo amino Acid composition to predict protease families by incorporating a series of protein biological features. Protein and Peptide Letters 18(6): 552-558.

85. Y Huang, L Yang, T Wang (2011) Phylogenetic analysis of DNA sequences based on the generalized pseudo amino acid composition. Journal of Theoretical Biology 269(1): 217-223.

86. Jingbo X, Silan Z, Feng S, Huijuan X, Xuehai H, et al. (2011) Using the concept of pseudo amino acid composition to predict resistance gene against Xanthomonas oryzae pv. oryzae in rice: An approach from chaos games representation. Journal of Theoretical Biology 284(1): 16-23.

87. Liao B, Jiang JB, Zeng QG, Zhu W (2011) Predicting Apoptosis Protein Subcellular Location with PseAAC by Incorporating Tripeptide Composition. Protein \& Peptide Letters 18(11): 1086-1092.

88. H Lin, H Ding (2011) Predicting ion channels and their types by the dipeptide mode of pseudo amino acid composition. Journal of Theoretical Biology 269(1): 64-69.

89. J Lin, Y Wang (2011) Using a novel AdaBoost algorithm and Chou's pseudo amino acid composition for predicting protein subcellular localization. Protein \& Peptide Letters 18(12): 1219-1225.

90. J Lin, Y Wang, X Xu (2011) A novel ensemble and composite approach for classifying proteins based on Chou's pseudo amino acid composition. African Journal of Biotechnology 10(74): 16963-16968.

91. Liu XL, Lu JL, Hu XH (2011) Predicting Thermophilic Proteins with Pseudo Amino Acid Composition: Approached from Chaos Game Representation and Principal Component Analysis. Protein \& Peptide Letters 18(12): 1244-1250.

92. A Mahdavi, S Jahandideh (2011) Application of density similarities to predict membrane protein types based on pseudo amino acid composition. Journal of Theoretical Biology 276(1): 132-137.

93. Mohabatkar H, Mohammad Beigi M, Esmaeili A (2011) Prediction of GABA(A) receptor proteins using the concept of Chou's pseudo amino acid composition and support vector machine. Journal of Theoretical Biology 281(1): 18-23.

94. Mohammad Beigi M, Behjati M, Mohabatkar H (2011) Prediction of metalloproteinase family based on the concept of Chou's pseudo amino acid composition using a machine learning approach. Journal of Structural and Functional Genomics 12(4): 191-197.

95. Qiu JD, Sun XY, Suo SB, Shi SP, Huang SY, et al. (2011) Predicting homooligomers and hetero-oligomers by pseudo amino acid composition: an approach from discrete wavelet transformation. Biochimie 93(7): 11321138.

96. JD Qiu, SB Suo, XY Sun, SP Shi, RP Liang (2011) OligoPred: A web-server for predicting homo-oligomeric proteins by incorporating discrete wavelet transform into Chou's pseudo amino acid composition. Journal of Molecular Graphics \& Modelling 30: 129-134.

97. R Shi, C Xu (2011) Prediction of rat protein subcellular localization with pseudo amino Acid composition based on multiple sequential features. Protein and Peptide Letters 18(6): 625-633.

98. Shu M, Cheng X, Zhang Y, Wang Y, Lin Y, et al. (2011) Predicting the Activity of ACE Inhibitory Peptides with a Novel Mode of Pseudo Amino Acid Composition. Protein \& Peptide Letters 18(12): 1233-1243.

99. Wang D, Yang L, Fu Z, Xia J (2011) Prediction of thermophilic protein with pseudo amino Acid composition: an approach from combined feature selection and reduction. Protein \& Peptide Letters 18(7): 684689. 
100. Wang W, Geng X, Dou Y, Liu T, Zheng X (2011) Predicting protein subcellular localization by pseudo amino Acid composition with a segment-weighted and features-combined approach. Protein and Peptide Letters 18(5): 480-487.

101. X Xiao, KC Chou (2011) Using pseudo amino acid composition to predict protein attributes via cellular automata and other approaches. Current Bioinformatics 6(2): 251-260.

102. X Xiao, P Wang, KC Chou (2011) GPCR-2L: Predicting G proteincoupled receptors and their types by hybridizing two different modes of pseudo amino acid compositions. Molecular Biosystems 7(3): 911 919.

103. R Zia Ur, A Khan (2011) Prediction of GPCRs with Pseudo Amino Acid Composition: Employing Composite Features and Grey Incidence Degree Based Classification. Protein \& Peptide Letters 18(9): 872-878.

104. D Zou, Z He, J He, Y Xia (2011) Super secondary structure prediction using Chou's pseudo amino acid composition. Journal of Computational Chemistry 32: 271-278.

105. JZ Cao, WQ Liu, H Gu (2012) Predicting Viral Protein Subcellular Localization with Chou's Pseudo Amino Acid Composition and Imbalance-Weighted Multi-Label K-Nearest Neighbor Algorithm. Protein and Peptide Letters 19(11): 1163-1169.

106. C Chen, ZB Shen, XY Zou (2012) Dual-Layer Wavelet SVM for Predicting Protein Structural Class Via the General Form of Chou's Pseudo Amino Acid Composition. Protein \& Peptide Letters 19(4): 422-429.

107. YL Chen, QZ Li, LQ Zhang (2012) Using increment of diversity to predict mitochondrial proteins of malaria parasite: integrating pseudo amino acid composition and structural alphabet. Amino Acids 42(4) 1309-1316.

108. GL Fan, QZ Li (2012) Predict mycobacterial proteins subcellular locations by incorporating pseudo-average chemical shift into the general form of Chou's pseudo amino acid composition. Journal of Theoretical Biology 304: 88-95.

109. GL Fan, QZ Li (2012) Predicting protein submitochondria locations by combining different descriptors into the general form of Chou's pseudo amino acid composition. Amino Acids 43(2): 545-555.

110. QB Gao, H Zhao, X Ye, J He (2012) Prediction of pattern recognition receptor family using pseudo amino acid composition. Biochemical and Biophysical Research Communications 417(1): 73-77.

111. M Hayat, A Khan (2012) Discriminating Outer Membrane Proteins with Fuzzy K-Nearest Neighbor Algorithms Based on the General Form of Chou's PseAAC. Protein \& Peptide Letters 19(4): 411-421.

112. LQ Li, Y Zhang, LY Zou, Y Zhou, XQ Zheng, et al. (2012) Prediction of Protein Subcellular Multi-Localization Based on the General form of Chou's Pseudo Amino Acid Composition. Protein \& Peptide Letters 19(4): 375-387.

113. B Liao, Q Xiang, D Li (2012) Incorporating Secondary Features into the General form of Chou's PseAAC for Predicting Protein Structural Class. Protein \& Peptide Letters 19(11): 1133-1138.

114. WZ Lin, JA Fang, X Xiao, KC Chou (2012) Predicting Secretory Proteins of Malaria Parasite by Incorporating Sequence Evolution Information into Pseudo Amino Acid Composition via Grey System Model. PLoS One 7: e49040.

115. L Liu, XZ Hu, XX Liu, Y Wang, SB Li (2012) Predicting Protein Fold Types by the General Form of Chou's Pseudo Amino Acid Composition: Approached from Optimal Feature Extractions. Protein \& Peptide Letters 19(4): 439-449.

116. S Mei (2012) Multi-kernel transfer learning based on Chou's PseAAC formulation for protein submitochondria localization. Journal of Theoretical Biology 293: 121-130.

117. S Mei (2012) Predicting plant protein subcellular multi-localization by Chou's PseAAC formulation based multi-label homolog knowledge transfer learning. Journal of Theoretical Biology 310: 80-87.
118. L Nanni, S Brahnam, A Lumini (2012) Wavelet images and Chou's pseudo amino acid composition for protein classification. Amino Acids 43(2): 657-65.

119. L Nanni, A Lumini, D Gupta, A Garg (2012) Identifying bacterial virulent proteins by fusing a set of classifiers based on variants of Chou's pseudo amino acid composition and on evolutionary information. IEEE-ACM Transaction on Computational Biolology and Bioinformatics 9(2): 467-475.

120. XH Niu, XH Hu, F Shi, JB Xia (2012) Predicting Protein Solubility by the General Form of Chou's Pseudo Amino Acid Composition: Approached from Chaos Game Representation and Fractal Dimension. Protein \& Peptide Letters 19(9): 940-948.

121. YF Qin, CH Wang, XQ Yu, J Zhu, TG Liu, et al. (2012) Predicting Protein Structural Class by Incorporating Patterns of Over- Represented k-mers into the General form of Chou's PseAAC. Protein \& Peptide Letters 19(4): 388-397.

122. LY Ren, YS Zhang, I Gutman (2012) Predicting the Classification of Transcription Factors by Incorporating their Binding Site Properties into a Novel Mode of Chou's Pseudo Amino Acid Composition. Protein \& Peptide Letters 19(11): 1170-1176.

123. XY Sun, SP Shi, JD Qiu, SB Suo, SY Huang, et al. (2012) Identifying protein quaternary structural attributes by incorporating physicochemical properties into the general form of Chou's PseAAC via discrete wavelet transform. Molecular BioSystems 8(12): 3178-3184.

124. J Wang, Y Li, Q Wang, X You, J Man, et al. (2012) ProClusEnsem: predicting membrane protein types by fusing different modes of pseudo amino acid composition. Comput Biol Med 42(5): 564-574.

125. X Yu, X Zheng, T Liu, Y Dou, J Wang (2012) Predicting subcellular location of apoptosis proteins with pseudo amino acid composition: approach from amino acid substitution matrix and auto covariance transformation. Amino Acids 42(5): 1619-1625.

126. XW Zhao, ZQ Ma, MH Yin (2012) Predicting protein-protein interactions by combing various sequence- derived features into the general form of Chou's Pseudo amino acid composition. Protein \& Peptide Letters 19(8): 492-500.

127. Zia ur Rehman, A Khan (2012) Identifying GPCRs and their Types with Chou's Pseudo Amino Acid Composition: An Approach from Multiscale Energy Representation and Position Specific Scoring Matrix. Protein \& Peptide Letters 19(8): 890-903.

128. TH Chang, LC Wu, TY Lee, SP Chen, HD Huang, et al. (2013) EuLoc: a webserver for accurately predict protein subcellular localization in eukaryotes by incorporating various features of sequence segments into the general form of Chou's PseAAC. Journal of Computer-Aided Molecular Design 27(1): 91-103.

129. YK Chen, KB Li (2013) Predicting membrane protein types by incorporating protein topology, domains, signal peptides, and physicochemical properties into the general form of Chou's pseudo amino acid composition. Journal of Theoretical Biology 318: 1-12.

130. GL Fan, QZ Li, YC Zuo (2013) Predicting acidic and alkaline enzymes by incorporating the average chemical shift and gene ontology informations into the general form of Chou's PseAAC. Pocess Biochemistry 48(7): 1048-1053.

131. GL Fan, QZ Li (2013) Discriminating bioluminescent proteins by incorporating average chemical shift and evolutionary information into the general form of Chou's pseudo amino acid composition. Journal of Theoretical Biology 334: 45-51.

132. DN Georgiou, TE Karakasidis, AC Megaritis (2013) A short survey on genetic sequences, Chou's pseudo amino acid composition and its combination with fuzzy set theory. The Open Bioinformatics Journal 7: 41-48.

133. MK Gupta, R Niyogi, M Misra (2013) An alignment-free method to find similarity among protein sequences via the general form of Chou's pseudo amino acid composition. SAR QSAR Environ Res 24(7): 597609. 
134. C Huang, J Yuan (2013) Using radial basis function on the general form of Chou's pseudo amino acid composition and PSSM to predict subcellular locations of proteins with both single and multiple sites. Biosystems 113(1): 50-57.

135. C Huang, JQ Yuan (2013) A multilabel model based on Chou's pseudo amino acid composition for identifying membrane proteins with both single and multiple functional types. J Membr Biol 246(4): 327-334.

136. C Huang, JQ Yuan (2013) Predicting protein subchloroplast locations with both single and multiple sites via three different modes of Chou's pseudo amino acid compositions. Journal of Theoretical Biology 335: 205-212.

137. M Khosravian, FK Faramarzi, MM Beigi, M Behbahani, H Mohabatkar, et al. (2013) Predicting Antibacterial Peptides by the Concept of Chou's Pseudo amino Acid Composition and Machine Learning Methods. Protein \& Peptide Letters 20(2): 180-186.

138. H Lin, C Ding, LF Yuan, W Chen, H Ding, et al. (2013) Predicting subchloroplast locations of proteins based on the general form of Chou's pseudo amino acid composition: approached from optimal tripeptide composition. International Journal of Biomathematics 6: 1350003.

139. B Liu, X Wang, Q Zou, Q Dong, Q Chen, et al. (2013) Protein remote homology detection by combining Chou's pseudo amino acid composition and profile-based protein representation. Molecular Informatics 32: 775-782.

140. H Mohabatkar, MM Beigi, K Abdolahi, S Mohsenzadeh (2013) Prediction of Allergenic Proteins by Means of the Concept of Chou's Pseudo Amino Acid Composition and a Machine Learning Approach. Medicinal Chemistry 9(1): 133-137.

141. E Pacharawongsakda, T Theeramunkong (2013) Predict Subcellular Locations of Singleplex and Multiplex Proteins by Semi-Supervised Learning and Dimension-Reducing General Mode of Chou's PseAAC IEEE Transactions on Nanobioscience 12(4): 311-320.

142. YF Qin, L Zheng, J Huang (2013) Locating apoptosis proteins by incorporating the signal peptide cleavage sites into the general form of Chou's Pseudo amino acid composition. International Journal of Quantum Chemistry 113: 1660-1667.

143. AN Sarangi, M Lohani, R Aggarwal (2013) Prediction of Essential Proteins in Prokaryotes by Incorporating Various Physico-chemical Features into the General form of Chou's Pseudo Amino Acid Composition. Protein Pept Lett 20(7): 781-95.

144. S Wan, MW Mak, SY Kung (2013) GOASVM: A subcellular location predictor by incorporating term-frequency gene ontology into the general form of Chou's pseudo amino acid composition. Journal of Theoretical Biology 323: 40-48.

145. X Wang, GZ Li, WC Lu (2013) Virus-ECC-mPLoc: a multi-label predictor for predicting the subcellular localization of virus proteins with both single and multiple sites based on a general form of Chou's pseudo amino acid composition. Protein \& Peptide Letters 20(3): 309-317.

146. X Xiao, JL Min, P Wang, KC Chou (2013) iCDI-PseFpt: Identify the channel-drug interaction in cellular networking with PseAAC and molecular fingerprints. Journal of Theoretical Biology 337: 71-79.

147. N Xiaohui, L Nana, X Jingbo, C Dingyan, P Yuehua, et al. (2013) Using the concept of Chou's pseudo amino acid composition to predict protein solubility: An approach with entropies in information theory. Journal of Theoretical Biology 332: 211-217.

148. HL Xie, L Fu, XD Nie (2013) Using ensemble SVM to identify human GPCRs N-linked glycosylation sites based on the general form of Chou's PseAAC. Protein Eng Des Sel 26(11): 735-742.

149. Y Xu, J Ding, LY Wu, KC Chou (2013) iSNO-PseAAC: Predict cysteine S-nitrosylation sites in proteins by incorporating position specific amino acid propensity into pseudo amino acid composition. PLoS ONE 8(2): e55844
150. Y Xu, XJ Shao, LY Wu, NY Deng, KC Chou, et al. (2013) iSNO-AAPair: incorporating amino acid pairwise coupling into PseAAC for predicting cysteine S-nitrosylation sites in proteins. PeerJ 1: e171.

151. Z Hajisharifi, M Piryaiee, M Mohammad Beigi, M Behbahani, H Mohabatkar, et al. (2014) Predicting anticancer peptides with Chou's pseudo amino acid composition and investigating their mutagenicity via Ames test. Journal of Theoretical Biology 341: 34-40.

152. GS Han, ZG Yu, V Anh (2014) A two-stage SVM method to predict membrane protein types by incorporating amino acid classifications and physicochemical properties into a general form of Chou's PseAAC. J Theor Biol 344: 31-39.

153. M Hayat, N Iqbal (2014) Discriminating protein structure classes by incorporating Pseudo Average Chemical Shift to Chou's general PseAAC and Support Vector Machine. Comput Methods Programs Biomed 116(3): 184-192.

154. C Jia, X Lin, Z Wang (2014) Prediction of Protein S-Nitrosylation Sites Based on Adapted Normal Distribution Bi-Profile Bayes and Chou's Pseudo Amino Acid Composition. Int J Mol Sci 15(6): 10410-10423.

155. L Kong, L Zhang, J Lv (2014) Accurate prediction of protein structural classes by incorporating predicted secondary structure information into the general form of Chou's pseudo amino acid composition. J Theor Biol 344: 12-18.

156. L Li, S Yu, W Xiao, Y Li, M Li, et al. (2014) Prediction of bacterial protein subcellular localization by incorporating various features into Chou's PseAAC and a backward feature selection approach. Biochimie 104 : 100-107.

157. B Liu, J Xu, X Lan, R Xu, J Zhou, et al. (2014) iDNA-Prot|dis: identifying DNA-binding proteins by incorporating amino acid distance-pairs and reduced alphabet profile into the general pseudo amino acid composition. PLoS ONE 9: e106691.

158. S Mondal, PP Pai (2014) Chou's pseudo amino acid composition improves sequence-based antifreeze protein prediction. J Theor Biol 356: 30-35.

159. L Nanni, S Brahnam, A Lumini (2014) Prediction of protein structure classes by incorporating different protein descriptors into general Chou's pseudo amino acid composition. J Theor Biol 360: 109-116.

160. WR Qiu, X Xiao, KC Chou (2014) iRSpot-TNCPseAAC: Identify recombination spots with trinucleotide composition and pseudo amino acid components. Int J Mol Sci (IJMS) 15(2): 1746-1766.

161. WR Qiu, X Xiao, WZ Lin, KC Chou (2014) iMethyl-PseAAC: Identification of Protein Methylation Sites via a Pseudo Amino Acid Composition Approach. Biomed Res Int (BMRI) 947416.

162. Y Xu, X Wen, XJ Shao, NY Deng, KC Chou, et al. (2014) iHyd-PseAAC: Predicting hydroxyproline and hydroxylysine in proteins by incorporating dipeptide position-specific propensity into pseudo amino acid composition. International Journal of Molecular Sciences (IJMS) 15(5): 7594-7610.

163. Y Xu, X Wen, LS Wen, LY Wu, NY Deng, et al. (2014) iNitro-Tyr: Prediction of nitrotyrosine sites in proteins with general pseudo amino acid composition. PLoS ONE 9: e105018.

164. J Zhang, P Sun, X Zhao, Z Ma (2014) PECM: Prediction of extracellular matrix proteins using the concept of Chou's pseudo amino acid composition. Journal of Theoretical Biology 363: 412-418.

165. J Zhang, X Zhao, P Sun, Z Ma (2014) PSNO: Predicting Cysteine S-Nitrosylation Sites by Incorporating Various Sequence-Derived Features into the General Form of Chou's PseAAC. Int J Mol Sci 15(7): 11204-11219.

166. L Zhang, X Zhao, L Kong (2014) Predict protein structural class for lowsimilarity sequences by evolutionary difference information into the general form of Chou's pseudo amino acid composition. J Theor Biol 355: 105-110 
167. S Ahmad, M Kabir, M Hayat (2015) Identification of Heat Shock Protein families and J-protein types by incorporating Dipeptide Composition into Chou's general PseAAC. Comput Methods Programs Biomed 122(2): 165-174.

168. F Ali, M Hayat (2015) Classification of membrane protein types using Voting Feature Interval in combination with Chou's Pseudo Amino Acid Composition. J Theor Biol 384: 78-83.

169. L Chen, C Chu, T Huang, X Kong, YD Cai, et al. (2015) Prediction and analysis of cell-penetrating peptides using pseudo amino acid composition and random forest models. Amino Acids 47(7):14851493.

170. A Dehzangi, R Heffernan, A Sharma, J Lyons, K Paliwal, et al. (2015) Gram-positive and Gram-negative protein subcellular localization by incorporating evolutionary-based descriptors into Chou's general PseAAC. J Theor Biol 364: 284-294.

171. C Huang, JQ Yuan (2015) Simultaneously Identify Three Different Attributes of Proteins by Fusing their Three Different Modes of Chou's Pseudo Amino Acid Compositions. Protein Pept Lett 22(6): 547-556.

172. J Jia, Z Liu, X Xiao, KC Chou (2015) iPPI-Esml: an ensemble classifier for identifying the interactions of proteins by incorporating their physicochemical properties and wavelet transforms into PseAAC. J Theor Biol 377: 47-56.

173. Z Ju, JZ Cao, H Gu (2015) iLM-2L: A two-level predictor for identifying protein lysine methylation sites and their methylation degrees by incorporating K-gap amino acid pairs into Chous general PseAAC. Theor Biol 385: 50-57.

174. ZU Khan, M Hayat, MA Khan (2015) Discrimination of acidic and alkaline enzyme using Chou's pseudo amino acid composition in conjunction with probabilistic neural network model. J Theor Bio 365: 197-203.

175. R Kumar, A Srivastava, B Kumari, M Kumar (2015) Prediction of betalactamase and its class by Chou's pseudo amino acid composition and support vector machine. J Theor Biol 365: 96-103.

176. B Liu, J Chen, X Wang (2015) Protein remote homology detection by combining Chou's distance-pair pseudo amino acid composition and principal component analysis. Mol Genet Genomics 290(5): 1919 1931.

177. B Liu, J Xu, S Fan, R Xu, J Jiyun Zhou, et al. (2015) PseDNA-Pro: DNAbinding protein identification by combining Chou's PseAAC and physicochemical distance transformation. Molecular Informatics 34(1): 8-17

178. M Mandal, A Mukhopadhyay, U Maulik (2015) Prediction of protein subcellular localization by incorporating multiobjective PSO-based feature subset selection into the general form of Chou's PseAAC. Med Biol Eng Comput 53(4): 331-344.

179. V Sanchez, AM Peinado, JL Perez Cordoba, AM Gomez (2015) A new signal characterization and signal-based Chou's PseAAC representation of protein sequences. J Bioinform Comput Biol 13(5): 1550024.

180. R Sharma, A Dehzangi, J Lyons, K Paliwal, T Tsunoda, et al. (2015) Predict Gram-Positive and Gram-Negative Subcellular Localization via Incorporating Evolutionary Information and Physicochemical Features Into Chou's General PseAAC. IEEE Trans Nanobioscience 14(8): 915-926.

181. X Wang, W Zhang, Q Zhang, GZ Li (2015) MultiP-SChlo: multilabel protein subchloroplast localization prediction with Chou's pseudo amino acid composition and a novel multi-label classifier. Bioinformatics 31(16): 2639-2645.

182. R Xu, J Zhou, B Liu, YA He, Q Zou, et al. (2015) Identification of DNAbinding proteins by incorporating evolutionary information into pseudo amino acid composition via the top-n-gram approach. Journal of Biomolecular Structure \& Dynamics (JBSD) 33(8): 1720-1730.

183. M Zhang, B Zhao, X Liu (2015) Predicting industrial polymer melt index via incorporating chaotic characters into Chou's general PseAAC
Chemometrics and Intelligent Laboratory Systems (CHEMOLAB) 146: 232-240.

184. SL Zhang (2015) Accurate prediction of protein structural classes by incorporating PSSS and PSSM into Chou's general PseAAC. Chemometrics and Intelligent Laboratory Systems (CHEMOLAB) 142: 28-35.

185. PP Zhu, WC Li, ZJ Zhong, EZ Deng, H Ding, et al. (2015) Predicting the subcellular localization of mycobacterial proteins by incorporating the optimal tripeptides into the general form of pseudo amino acid composition. Mol Biosyst 1: 558-563.

186. K Ahmad, M Waris, M Hayat (2016) Prediction of Protein Submitochondrial Locations by Incorporating Dipeptide Composition into Chou's General Pseudo Amino Acid Composition. J Membr Biol 249(3): 293-304.

187. M Behbahani, H Mohabatkar, M Nosrati (2016) Analysis and comparison of lignin peroxidases between fungi and bacteria using three different modes of Chou's general pseudo amino acid composition. J Theor Biol 411: $1-5$.

188. GL Fan, YL Liu, H Wang (2016) Identification of thermophilic proteins by incorporating evolutionary and acid dissociation information into Chou's general pseudo amino acid composition. J Theor Biol 407: 138142.

189. J Jia, Z Liu, X Xiao, B Liu, KC Chou (2016) Identification of proteinprotein binding sites by incorporating the physicochemical properties and stationary wavelet transforms into pseudo amino acid composition (iPPBS-PseAAC). J Biomol Struct Dyn (JBSD) 34(9): 1946-1961.

190. J Jia, Z Liu, X Xiao, B Liu, KC Chou (2016) pSuc-Lys: Predict lysine succinylation sites in proteins with PseAAC and ensemble random forest approach. Journal of Theoretical Biology 394: 223-230.

191. J Jia, Z Liu, X Xiao, B Liu, KC Chou, et al. (2016) iCar-PseCp: identify carbonylation sites in proteins by Monto Carlo sampling and incorporating sequence coupled effects into general PseAAC. Oncotarget 7(23): 34558-34570.

192. J Jia, L Zhang, Z Liu, X Xiao, KC Chou, et al. (2016) pSumo-CD: Predicting sumoylation sites in proteins with covariance discriminant algorithm by incorporating sequence-coupled effects into general PseAAC. Bioinformatics 32(20): 3133-3141.

193. YS Jiao, PF Du (2016) Prediction of Golgi-resident protein types using general form of Chou's pseudo amino acid compositions: Approaches with minimal redundancy maximal relevance feature selection. J Theor Biol 402: 38-44.

194. Z Ju, JZ Cao, H Gu (2016) Predicting lysine phosphoglycerylation with fuzzy SVM by incorporating k-spaced amino acid pairs into Chou's general PseAAC. J Theor Biol 397: 145-150.

195. M Kabir, M Hayat (2016) iRSpot-GAEnsC: identifing recombination spots via ensemble classifier and extending the concept of Chou's PseAAC to formulate DNA samples. Molecular Genetics and Genomics 291(1): 285-296.

196. WR Qiu, BQ Sun, X Xiao, ZC Xu, KC Chou, et al. (2016) iHyd-PseCp: Identify hydroxyproline and hydroxylysine in proteins by incorporating sequence-coupled effects into general PseAAC. Oncotarget 7(28): $44310-44321$

197. M Tahir, M Hayat (2016) iNuc-STNC: a sequence-based predictor for identification of nucleosome positioning in genomes by extending the concept of SAAC and Chou's PseAAC. Mol Biosyst 12: 2587-2593.

198. H Tang, W Chen, H Lin (2016) Identification of immunoglobulins using Chou's pseudo amino acid composition with feature selection technique. Mol Biosyst 12(4): 1269-1275.

199. AK Tiwari (2016) Prediction of G-protein coupled receptors and their subfamilies by incorporating various sequence features into Chou's general PseAAC. Comput Methods Programs Biomed 134: 197-213.

200. C Xu, D Sun, S Liu, Y Zhang (2016) Protein Sequence Analysis by Incorporating Modified Chaos Game and Physicochemical Properties 
into Chou's General Pseudo Amino Acid Composition. J Theor Biol 406 105-115.

201. HL Zou, X Xiao (2016) Predicting the Functional Types of Singleplex and Multiplex Eukaryotic Membrane Proteins via Different Models of Chou's Pseudo Amino Acid Compositions. J Membr Biol 249(1): 23-29.

202. HL Zou, X Xiao (2016) Classifying Multifunctional Enzymes by Incorporating Three Different Models into Chou's General Pseudo Amino Acid Composition. J Membr Biol 249(4): 561-567.

203. X Cheng, X Xiao, KC Chou (2017) pLoc-mPlant: predict subcellular localization of multi-location plant proteins via incorporating the optimal GO information into general PseAAC. Molecular BioSystems 13(9): 1722-1727.

204. X Cheng, X Xiao, KC Chou (2017) pLoc-mVirus: predict subcellular localization of multi-location virus proteins via incorporating the optimal GO information into general PseAAC. Gene 628: 315-321.

205. Z Ju, JJ He (2017) Prediction of lysine propionylation sites using biased SVM and incorporating four different sequence features into Chou's PseAAC. J Mol Graph Model 76: 356-363.

206. Z Ju, JJ He (2017) Prediction of lysine crotonylation sites by incorporating the composition of k-spaced amino acid pairs into Chou's general PseAAC. J Mol Graph Model 77: 200-204.

207. M Khan, M Hayat, SA Khan, N Iqbal (2017) Unb-DPC: Identify mycobacterial membrane protein types by incorporating un-biased dipeptide composition into Chou's general PseAAC. J Theor Biol 415: 13-19.

208. Y Liang, S Zhang (2017) Predict protein structural class by incorporating two different modes of evolutionary information into Chou's general pseudo amino acid composition. J Mol Graph Model 78: 110-117.

209. LM Liu, Y Xu, KC Chou (2017) iPGK-PseAAC: identify lysine phosphoglycerylation sites in proteins by incorporating four different tiers of amino acid pairwise coupling information into the general PseAAC. Med Chem 13(6): 552-559.

210. Meher PK, Sahu TK, Saini V, Rao AR (2017) Predicting antimicrobial peptides with improved accuracy by incorporating the compositional, physico-chemical and structural features into Chou's general PseAAC. Sci Rep 7: 42362.

211. Qiu WR, Sun BQ Xiao X, Xu D, Chou KC (2017) iPhos-PseEvo: Identifying human phosphorylated proteins by incorporating evolutionary information into general PseAAC via grey system theory. Molecular Informatics 36: UNSP 1600010.

212. Wang-Ren Qiu, Quan-Shu Zheng, Bi-Qian Sun, Xuan Xiao (2017) Multi-iPPseEvo: A Multi-label Classifier for Identifying Human Phosphorylated Proteins by Incorporating Evolutionary Information into Chou's General PseAAC via Grey System Theory. Mol Inform 36 UNSP 1600085.

213. Rahimi M, Bakhtiarizadeh MR, Mohammadi-Sangcheshmeh A (2017) OOgenesis_Pred: A sequence-based method for predicting oogenesis proteins by six different modes of Chou's pseudo amino acid composition. J Theor Biol 414: 128-136.

214. Tripathi P, Pandey PN (2017) A novel alignment-free method to classify protein folding types by combining spectral graph clustering with Chou's pseudo amino acid composition. J Theor Biol 424: 49-54.

215. Xiao X, Cheng X, Su S, Nao Q Chou KC (2017) pLoc-mGpos: Incorporate key gene ontology information into general PseAAC for predicting subcellular localization of Gram-positive bacterial proteins. Natural Science 9:331-349.

216. Xu C, Ge L, Zhang Y, Dehmer M, Gutman I (2017)Prediction of therapeutic peptides by incorporating q-Wiener index into Chou's general PseAAC. J Biomed Inform.

217. Xu Y, Wang Z, Li C, Chou KC (2017) iPreny-PseAAC: identify C-terminal cysteine prenylation sites in proteins by incorporating two tiers of sequence couplings into PseAAC. Med Chem 13: 544-551.
218. Bin Yu,Shan Li,Wen-Ying Qiu,Cheng Chen,Rui-Xin Chenet al. (2017) Accurate prediction of subcellular location of apoptosis proteins combining Chou's PseAAC and PsePSSM based on wavelet denoising. Oncotarget 8: 107640-107665.

219. Yu B, Lou L, Li S, Zhang Y, Qiu W, et al. (2017) Prediction of protein structural class for low-similarity sequences using Chou's pseudo amino acid composition and wavelet denoising. J Mol Graph Model 76: 260-273.

220. Ahmad J, Hayat M (2018) MFSC: Multi-voting-based Feature Selection for Classification of Golgi Proteins by Adopting the General form of Chou's PseAAC components. J Theor Biol 463: 99-109.

221. Akbar S, Hayat M (2018) iMethyl-STTNC: Identification of N(6)methyladenosine sites by extending the Idea of SAAC into Chou's PseAAC to formulate RNA sequences. J Theor Biol 455: 205-211.

222. Arif M, Hayat M, Jan Z (2018) iMem-2LSAAC: A two-level model for discrimination of membrane proteins and their types by extending the notion of SAAC into Chou's pseudo amino acid composition. J Theor Biol 442: 11-21.

223. Butt AH, Rasool N,Khan YD (2018) Predicting membrane proteins and their types by extracting various sequence features into Chou's general PseAAC. Mol Biol Rep 45(6): 2295-2306.

224. Cheng X, Xiao X, Chou KC (2018) pLoc-mEuk: Predict subcellular localization of multi-label eukaryotic proteins by extracting the key GO information into general PseAAC. Genomics 110: 50-58.

225. Cheng X, Xiao X, Chou KC (2018) pLoc-mGneg: Predict subcellular localization of Gram-negative bacterial proteins by deep gene ontology learning via general PseAAC. Genomics 110: 231-239.

226. Cheng X, Xiao X, Chou KC (2018) pLoc-mHum: predict subcellular localization of multi-location human proteins via general PseAAC to winnow out the crucial GO information. Bioinformatics 34(9): 14481456.

227. Cheng X, Xiao X, Chou KC (2018) pLoc_bal-mGneg: predict subcellular localization of Gram-negative bacterial proteins by quasi-balancing training dataset and general PseAAC. Journal of Theoretical Biology 458: 92-102.

228. Cheng X, Xiao X, Chou KC (2018) pLoc_bal-mPlant: predict subcellular localization of plant proteins by general PseAAC and balancing training dataset Curr Pharm Des 24(34): 4013-4022.

229. Chou KC, Cheng X, Xiao X (2018) pLoc_bal-mHum: predict subcellular localization of human proteins by PseAAC and quasi-balancing training dataset. Genomics 111(6): 1274-1282

230. Chou KC, Cheng X, Xiao X (2019) pLoc_bal-mEuk: predict subcellular localization of eukaryotic proteins by general PseAAC and quasibalancing training dataset. Med Chem 15(5): 472-485.

231. Contreras-Torres E (2018) Predicting structural classes of proteins by incorporating their global and local physicochemical and conformational properties into general Chou's PseAAC. J Theor Biol 454: $139-145$

232. Fu X, Zhu W, Liso B, Cai L, Peng L, et al. (2018) Improved DNA-binding protein identification by incorporating evolutionary information into the Chou's PseAAC. IEEE.

233. Ghauri AW, Khan YD, Rasool N, Khan SA, Chou KC (2018) pNitro-TyrPseAAC: Predict nitrotyrosine sites in proteins by incorporating five features into Chou's general PseAAC. Curr Pharm Des 24(34): 40344043.

234. Javed F,Hayat M (2018) Predicting subcellular localizations of multilabel proteins by incorporating the sequence features into Chou's PseAAC. Genomics 111(6): 1325-1332.

235. Ju Z, Wang SY (2018) Prediction of citrullination sites by incorporating k-spaced amino acid pairs into Chou's general pseudo amino acid composition. Gene 664: 78-83.

236. Khan YD, Rasool N, Hussain W,Khan SA,Chou KC (2018) iPhosTPseAAC: Identify phosphothreonine sites by incorporating sequence 
statistical moments into PseAAC. Analytical Biochemistry 550: 109116.

237. Khan YD, Rasool N, Hussain W, Khan SA,Choum KC (2018) iPhosYPseAAC: identify phosphotyrosine sites by incorporating sequence statistical moments into PseAAC. Mol Biol Rep 45 (6): 2501-2509.

238. Krishnan MS (2018) Using Chou's general PseAAC to analyze the evolutionary relationship of receptor associated proteins (RAP) with various folding patterns of protein domains. J Theor Biol 445: 62-74.

239. Liang Y, Zhang S (2018) Identify Gram-negative bacterial secreted protein types by incorporating different modes of PSSM into Chou's general PseAAC via Kullback-Leibler divergence. J Theor Biol 454: 2229.

240. Mei J, Fu Y, Zhao J (2018) Analysis and prediction of ion channel inhibitors by using feature selection and Chou's general pseudo amino acid composition. J Theor Biol 456: 41-48.

241. Mei J, Zhao J (2018) Prediction of HIV-1 and HIV-2 proteins by using Chou's pseudo amino acid compositions and different classifiers. Sci Rep 8: 2359.

242. Mei J, Zhao J(2018) Analysis and prediction of presynaptic and postsynaptic neurotoxins by Chou's general pseudo amino acid composition and motif features. J Theor Biol 447: 147-153.

243. Mousavizadegan M,Mohabatkar H (2018) Computational prediction of antifungal peptides via Chou's PseAAC and SVM. J Bioinform Comput Biol 16 (4): 1850016.

244. Rahman SM, Shatabda S, Saha S, Kaykobad M, Sohel Rahman M (2018) DPP-PseAAC: A DNA-binding Protein Prediction model using Chou's general PseAAC. J Theor Biol 452: 22-34.

245. Sankari ES, Manimegalai DD (2018) Predicting membrane protein types by incorporating a novel feature set into Chou's general PseAAC. J Theor Biol 455: 319-328.

246. Srivastava A, Kumar R, Kumar M (2018) BlaPred: predicting and classifying beta-lactamase using a 3-tier prediction system via Chou's general PseAAC. J Theor Biol 457: 29-36.

247. Zhang S, Duan X (2018) Prediction of protein subcellular localization with oversampling approach and Chou's general PseAAC. J Theor Biol 437: 239-250.

248. Zhang S, Liang Y (2018) Predicting apoptosis protein subcellular localization by integrating auto-cross correlation and PSSM into Chou's PseAAC. J Theor Biol 457: 163-169.

249. Adilina S, Farid DM Shatabda S (2019) Effective DNA binding protein prediction by using key features via Chou's general PseAAC. J Theor Biol 460: 64-78.

250. Ahmad J,Hayat M (2019) MFSC: Multi-voting based feature selection for classification of Golgi proteins by adopting the general form of Chou's PseAAC components. J Theor Biol 463: 99-109.

251. Awais M, Hussain W, Khan YD, Rasool N, Khan SA, et al. (2019) iPhosHPseAAC: Identify phosphohistidine sites in proteins by blending statistical moments and position relative features according to the Chou's 5-step rule and general pseudo amino acid composition. IEEE/ ACM Trans Comput Biol Bioinform.

252. Butt AH, Rasool N, Khan YD (2019) Prediction of antioxidant proteins by incorporating statistical moments-based features into Chou's PseAAC. Journal of Theoretical Biology 473: 1-8.

253. Chen G, Cao M, Yu J, Guo X, Shi S (2019) Prediction and functional analysis of prokaryote lysine acetylation site by incorporating six types of features into Chou's general PseAAC. J Theor Biol 461: 92-101.

254. Cheng X, Lin WZ, Xiao X, Chou KC (2019) pLoc_bal-mAnimal: predict subcellular localization of animal proteins by balancing training dataset and PseAAC. Bioinformatics 35(3): 398-406.

255. Ehsan A, Mahmood MK, Khan YD, Barukab OM, Khan SA, et al. (2019) iHyd-PseAAC (EPSV): Identify hydroxylation sites in proteins by extracting enhanced position and sequence variant feature via Chou's 5-step rule and general pseudo amino acid composition. Current Genomics 20(2): 124-133.

256. Hussain W, Khan SD, Rasool N, Khan SA, Chou KC (2019)SPalmitoylCPseAAC: A sequence-based model developed via Chou's 5-steps rule and general PseAAC for identifying S-palmitoylation sites in proteins. Anal Biochem 568: 14-23.

257. Hussain W, Khan YD, Rasool N, Khan SA, Chou KC (2019) SPrenylCPseAAC: A sequence-based model developed via Chou's 5-steps rule and general PseAAC for identifying S-prenylation sites in proteins. J Theor Biol 468: 1-11.

258. Jia J, Li X, Qiu W, Xiao X, Chou KC (2019) iPPI-PseAAC(CGR): Identify protein-protein interactions by incorporating chaos game representation into PseAAC. Journal of Theoretical Biology 460: 195203.

259. Kabir M, Ahmad S, Iqbal M, Hayat M (2019) iNR-2L: A two-level sequence-based predictor developed via Chou's 5-steps rule and general PseAAC for identifying nuclear receptors and their families. Genomics.

260. Khan YD, Jamil M,Hussain W, Rasool N, Khan SA, et al. (2019) pSSbondPseAAC: Prediction of disulfide bonding sites by integration of PseAAC and statistical moments. J Theor Biol 463: 47-55.

261. Ning Q Ma Z, Zhao X (2019) dForml(KNN)-PseAAC: Detecting formylation sites from protein sequences using K-nearest neighbor algorithm via Chou's 5-step rule and pseudo components. J Theor Biol 470: 43-49.

262. Shen Y, Tang J, Guo F (2019) Identification of protein subcellular localization via integrating evolutionary and physicochemical information into Chou's general PseAAC. J Theor Biol 462: 230-239.

263. Tahir M, Hayat M, Khan SA (2019) iNuc-ext-PseTNC: an efficient ensemble model for identification of nucleosome positioning by extending the concept of Chou's PseAAC to pseudo-tri-nucleotide composition. Mol Genet Genomics 294(1): 199-210.

264. Wang L, Zhang R, Mu Y (2019) Fu-SulfPred: Identification of Protein S-sulfenylation Sites by Fusing Forests via Chou's General PseAAC. J Theor Biol 461: 51-58.

265. Xiao X, Cheng X, Chen G,Mao Q, Chou KC(2019) pLoc_bal-mGpos: predict subcellular localization of Gram-positive bacterial proteins by quasi-balancing training dataset and PseAAC. Genomics 111(4): 886892.

266. Xiao X, Cheng X, Chen G, Mao Q Chou KC (2018)pLoc_bal-mVirus: Predict Subcellular Localization of Multi-Label Virus Proteins by Chou's General PseAAC and IHTS Treatment to Balance Training Dataset. Med Chem 15(5) : 496-509.

267. Shen HB, Chou KC (2008) PseAAC: a flexible web-server for generating various kinds of protein pseudo amino acid composition. Analytical Biochemistry 373(2): 386-388.

268. Du P, Wang X, Xu C, Gao Y (2012) PseAAC-Builder: A cross-platform stand-alone program for generating various special Chou's pseudo amino acid compositions. Analytical Biochemistry 425: 117-119.

269. Cao DS, Xu QS, Liang YZ (2013) propy: a tool to generate various modes of Chou's PseAAC. Bioinformatics 29(7): 960-962.

270. Du P, Gu S, Jiao Y (2014) PseAAC-General: Fast building various modes of general form of Chou's pseudo amino acid composition for largescale protein datasets. International Journal of Molecular Sciences 15(3): 3495-3506.

271. Chou KC (2009) Pseudo amino acid composition and its applications in bioinformatics, proteomics and system biology. Current Proteomics 6: 262-274.

272. Chou KC (2011) Some remarks on protein attribute prediction and pseudo amino acid composition (50th Anniversary Year Review, 5-steps rule). Journal of Theoretical Biology 273(1): 236-247. 
273. Chen W, Lei TY, Jin DC, Lin H, Chou KC (2014) PseKNC: a flexible web-server for generating pseudo K-tuple nucleotide composition. Analytical Biochemistry 456: 53-60.

274. Chen W, Lin H, Chou KC (2015) Pseudo nucleotide composition or PseKNC: an effective formulation for analyzing genomic sequences Mol BioSyst 11(10): 2620-2634.

275. Liu B, Yang F, Huang DS, Chou KC (2018) iPromoter-2L: a two-layer predictor for identifying promoters and their types by multi-windowbased PseKNC. Bioinformatics 34: 33-40.

276. Guo SH, Deng EZ, Xu LQ Ding H, Lin H, et al.(2014) iNuc-PseKNC: a sequence-based predictor for predicting nucleosome positioning in genomes with pseudo k-tuple nucleotide composition. Bioinformatics 30(11): 1522-1529.

277. Lin H, Deng EZ, Ding H, Chen W, Chou KC (2014) iPro54-PseKNC: a sequence-based predictor for identifying sigma-54 promoters in prokaryote with pseudo k-tuple nucleotide composition. Nucleic Acids Research 42(21): 12961-12972.

278. Chen W, Zhang X, Brooker J, Lin H, Zhang L, et al. (2015) PseKNC General: a cross-platform package for generating various modes of pseudo nucleotide compositions. Bioinformatics 31(1): 119-120.

279. Liu B, Fang L, Longn R, Lan X, Chou KC (2016) iEnhancer-2L: a twolayer predictor for identifying enhancers and their strength by pseudo k-tuple nucleotide composition. Bioinformatics 32: 362-369.

280. Xiao X, Ye HX, Liu Z, Jia JH, Chou KC (2016) iROS-gPseKNC: predicting replication origin sites in DNA by incorporating dinucleotide positionspecific propensity into general pseudo nucleotide composition. Oncotarget 7(23): 34180-34189.

281. Feng P, Ding H, Yang H, Chen W, Lin H, et al. (2017)iRNA-PseColl: Identifying the occurrence sites of different RNA modifications by incorporating collective effects of nucleotides into PseKNC. Molecular Therapy - Nucleic Acids 7: 155-163.

282. Qiu WR, Jiang SY, Sun BQ Xiao X, Cheng X, et al.(2017) iRNA-2methyl: identify RNA 2'-0-methylation sites by incorporating sequencecoupled effects into general PseKNC and ensemble classifier. Medicinal Chemistry 13(8): 734-743.

283. Liu B, Weng F, Huang DS, Chou KC (2018) iRO-3wPseKNC: Identify DNA replication origins by three-window-based PseKNC. Bioinformatics 34(18): 3086-3093.

284. Sabooh MF, Iqbal N, Khan M, Khan M, Maqbool HF (2018) Identifying 5-methylcytosine sites in RNA sequence using composite encoding feature into Chou's PseKNC. J Theor Biol 452: 1-9.

285. Su ZD, Huang Y, Zhang ZY, Zhao YW, Wang D, et al. (2018) iLoc-lncRNA: predict the subcellular location of lncRNAs by incorporating octamer composition into general PseKNC. Bioinformatics 34(24): 4196-4204.

286. Xiao X, Xu ZC, Qiu WR, Wang P, Ge HT, et al. (2018) iPSW(2L)-PseKNC: A two-layer predictor for identifying promoters and their strength by hybrid features via pseudo K-tuple nucleotide composition. Genomics.

287. Yang H, Qiu WR, Liu G, Guo FB, Chen W, et al. (2018) iRSpot-Pse6NC: Identifying recombination spots in Saccharomyces cerevisiae by incorporating hexamer composition into general PseKNC International Journal of Biological Sciences 14(8): 883-891.

288. Feng P, Yang H, Ding H, Lin H, Chen W, et al.(2019)iDNA6mA-PseKNC: Identifying DNA N(6)-methyladenosine sites by incorporating nucleotide physicochemical properties into PseKNC. Genomics 111(1): 96-102.

289. Nazari I, Tahir M, Tayari H, Chong KT (2019) iN6-Methyl (5-step): Identifying RNA N6-methyladenosine sites using deep learning mode via Chou's 5-step rules and Chou's general PseKNC. Chemometrics and Intelligent Laboratory Systems (CHEMOLAB).

290. Tahir M, Tayara H, Chong KT (2019) iRNA-PseKNC(2methyl): Identify RNA 2'-O-methylation sites by convolution neural network and Chou's pseudo components. J Theor Biol 465: 1-6.
291. Liu B, Liu F, Wang X, Chen J, Fang L, et al. (2015) Pse-in-One: a web server for generating various modes of pseudo components of DNA, RNA, and protein sequences. Nucleic Acids Research 43: W65-W71.

292. Liu B, Wu H, Chou KC (2017) Pse-in-One 2.0: An improved package of web servers for generating various modes of pseudo components of DNA, RNA, and protein sequences. Natural Science 9: 67-91.

293. Voet D, Voet JG, Pratt CW(2002) Fundamentals of Biochemistry, John Wiley \& Sons, New York, USA.

294. Chou KC, Chen NY (1977) The biological functions of low-frequency phonons. Scientia Sinica 20: 447-457.

295. Du QS, Wang SQ Wei DQ, Zhu Y, Guo H, et al. (2004) Polyprotein Cleavage Mechanism of SARS CoV Mpro and Chemical Modification of Octapeptide. Peptides 25: 1857-1864.

296. Chou KC(1996) Review: Prediction of human immunodeficiency virus protease cleavage sites in proteins. Analytical Biochemistry 233(1): $1-14$.

297. Liang GZ, Li SZ (2007) A new sequence representation as applied in better specificity elucidation for human immunodeficiency virus type 1 protease. Biopolymers 88: 401-412.

298. Nanni L, Lumini A (2008)Using ensemble of classifiers for predicting HIV protease cleavage sites in proteins. Amino Acids.

299. Shen HB, Chou KC (2008) HIVcleave: a web-server for predicting HIV protease cleavage sites in proteins. Analytical Biochemistry 375(2): 388-390.

300. Du QS, Sun H, Chou KC (2007) Inhibitor design for SARS coronavirus main protease based on "distorted key theory". Medicinal Chemistry 3: $1-6$.

301. Du QS, Wang S, Wei DQ Sirois S, Chou KC (2005) Molecular modelling and chemical modification for finding peptide inhibitor against SARS CoV Mpro. Analytical Biochemistry 337(2): 262-270.

302. Gan YR, Huang H, Huang, Rao CM, Zhao Y, et al. (2006) Synthesis and activity of an octapeptide inhibitor designed for SARS coronavirus main proteinase. Peptides 27: 622-625.

303. Chou KC, Jiang SP, Liu WM, Fee CH (1979) Graph theory of enzyme kinetics: 1. Steady-state reaction system. Scientia Sinica 22: 341-358.

304. Chou KC, Zhang CT, Maggiora GM (1997) Disposition of amphiphilic helices in heteropolar environments. PROTEINS: Structure, Function, and Genetics 28(1): 99-108.

305. Zhou GP (2011)The disposition of the LZCC protein residues in wenxiang diagram provides new insights into the protein-protein interaction mechanism. Journal of Theoretical Biology 284(1): 142148.

306. Zhou GP (2011) The Structural Determinations of the Leucine Zipper Coiled-Coil Domains of the cGMP-Dependent Protein Kinase I alpha and its Interaction with the Myosin Binding Subunit of the Myosin Light Chains Phosphase. Proteins \& Peptide Letters 18(10): 966-978.

307. Andrade MA, O’Donoghue SI, Rost B (1998) Adaptation of protein surfaces to subcellular location. J. Mol. Biol 276(2): 517-525.

308. Reinhardt A, Hubbard T (1998) Using neural networks for prediction of the subcellular location of proteins. Nucleic Acids Research 26(9): 2230-2236.

309. Yuan Z (1999) Prediction of protein subcellular locations using Markov chain models. FEBS Letters 451(1): 23-26.

310. Emanuelsson O, Nielsen H, Brunak S, Von Heijne G (2000) Predicting subcellular localization of proteins based on their N-terminal amino acid sequence. Journal of Molecular Biology 300(4): 1005-1016.

311. Nakai K(2000) Protein sorting signals and prediction of subcellular localization. Advances in Protein Chemistry 54: 277-344.

312. Chou KC, Shen HB (2007) Recent progresses in protein subcellular location prediction. Analytical Biochemistry 370(1):1-16. 
313. Chou KC, Shen HB (2008) Cell-PLoc: A package of Web servers for predicting subcellular localization of proteins in various organisms. Nature Protocols 39(2): 153-162.

314. Zhong WZ, Zhou SF(2014) Molecular science for drug development and biomedicine. Intenational Journal of Molecular Sciences 15(11) 20072-20078.

315. Du, Huang RB, Wang SQ, Chou KC (2010) Designing inhibitors of M2 proton channel against H1N1 swine influenza virus. PLoS ONE 5: e9388.

316. Wang SD, Cheng XC, Dong WL, Wang RL, Chou KC((2010) Three new powerful Oseltamivir derivatives for inhibiting the neuraminidase of influenza virus. Biochem Biophys Res Commun (BBRC) 401(2): 188191.

317. Li XB, Wang SQ Xu WR, Wang RL, Chou KC(2011) Novel Inhibitor Design for Hemagglutinin against H1N1 Influenza Virus by Core Hopping Method. PLoS One 6: e28111.

318. Ma Y, Wang SQ, Xu WR, Wang RL, Chou KC (2012) Design novel dual agonists for treating type-2 diabetes by targeting peroxisome proliferator-activated receptors with core hopping approach. PLoS One $7(6)$ : e38546.

319. Liu L, Ma Y, Wang RL, Xu WR, Wang SQ et al. (2013) Find novel dualagonist drugs for treating type 2 diabetes by means of cheminformatics. Drug Design, Development and Therapy 7: 279-287.

320. Chou KC, Shen HB (2006) Hum-PLoc: A novel ensemble classifier for predicting human protein subcellular localization. Biochem Biophys Res Commun (BBRC) 347(1): 150-157.

321. Chou KC, Shen HB (2006) Addendum to "Hum-PLoc: A novel ensemble classifier for predicting human protein subcellular localization". Biochem Biophys Res Commun (BBRC) 348(4): 1479.

322. Shen HB, Chou KC (2007) Gpos-PLoc: an ensemble classifier for predicting subcellular localization of Gram-positive bacterial proteins. Protein Engineering, Design, and Selection 20(1): 39-46.

323. Shen HB, Chou KC (2007) Virus-PLoc: A fusion classifier for predicting the subcellular localization of viral proteins within host and virusinfected cells. Biopolymers 85(3): 233-240.

324. Shen HB, Chou KC (2007) Nuc-PLoc: A new web-server for predicting protein subnuclear localization by fusing PseAA composition and PsePSSM. Protein Engineering, Design \& Selection 20(11): 561-567.

325. Shen HB, Yang J, Chou KC (2007) Euk-PLoc: an ensemble classifier for large-scale eukaryotic protein subcellular location prediction. Amino Acids 33(1): 57-67.

326. Chou KC, Shen HB (2010) Cell-PLoc 2.0: An improved package of webservers for predicting subcellular localization of proteins in various organisms. Natural Science 2(10): 1090-1103.

327. Chou KC, Wu ZC, Xiao X (2011) iLoc-Euk: A Multi-Label Classifier for Predicting the Subcellular Localization of Singleplex and Multiplex Eukaryotic Proteins. PLoS One 6: e18258.

328. Wu ZC, Xiao X, Chou KC (2011) iLoc-Plant: a multi-label classifier for predicting the subcellular localization of plant proteins with both single and multiple sites. Molecular BioSystems 7: 3287-3297.

329. Xiao X, Wu ZC, Chou KC (2011) iLoc-Virus: A multi-label learning classifier for identifying the subcellular localization of virus proteins with both single and multiple sites. Journal of Theoretical Biology 284(1): 42-51.

330. Chou KC, Wu ZC, Xiao X (2012) iLoc-Hum: Using accumulation-label scale to predict subcellular locations of human proteins with both single and multiple sites. Molecular Biosystems 8: 629-641.

331. Wu ZC, Xiao X, Chou KC (2012) iLoc-Gpos: A Multi-Layer Classifier for Predicting the Subcellular Localization of Singleplex and Multiplex Gram-Positive Bacterial Proteins. Protein \& Peptide Letters 19(1): $4-14$
332. Lin WZ, Fang JA, Xiao X, Chou KC (2013) iLoc-Animal: A multi-label learning classifier for predicting subcellular localization of animal proteins Molecular BioSystems 9: 634-644.

333. Cheng X, Zhao SG, Lin WZ, Xiao X, Chou KC (2017) pLoc-mAnimal: predict subcellular localization of animal proteins with both single and multiple sites. Bioinformatics 33(22): 3524-3531.

334. Chou KC (2019) Advance in predicting subcellular localization of multi-label proteins and its implication for developing multi-target drugs. Current Medicinal Chemistry 26(26): 4918-4943.

335. Chen W, Feng PM, Lin H, Chou KC (2013) iRSpot-PseDNC: identify recombination spots with pseudo dinucleotide composition Nucleic Acids Research 41(6): e68.

336. Feng PM, Chen W, Lin H, Chou KC (2013) iHSP-PseRAAAC: Identifying the heat shock protein families using pseudo reduced amino acid alphabet composition. Analytical Biochemistry 442(1): 118-125.

337. Chen W, Feng PM, Deng EZ, Lin H, Chou KC (2014) iTIS-PseTNC: a sequence-based predictor for identifying translation initiation site in human genes using pseudo trinucleotide composition. Analytical Biochemistry 462: 76-83.

338. Ding H, Deng EZ, Yuan LF, Liu L, Lin H, et al. (2014) iCTX-Type: A sequence-based predictor for identifying the types of conotoxins in targeting ion channels. BioMed Research International (BMRI) 2014: 286419

339. Liu B, Fang L, Liu F, Wang X, Chen J, et al. (2015) Identification of real microRNA precursors with a pseudo structure status composition approach. PLoS ONE 10: e0121501.

340. Liu Z, Xiao X, Qiu WR, Chou KC (2015) iDNA-Methyl: Identifying DNA methylation sites via pseudo trinucleotide composition. Analytical Biochemistry 474: 69-77.

341. Xiao X, Min JL, Lin WZ, Liu Z, Cheng X, et al. (2015) iDrug-Target: predicting the interactions between drug compounds and target proteins in cellular networking via the benchmark dataset optimization approach. J Biomol Struct Dyn (JBSD) 33(10): 2221-2233.

342. Jia J, Liu Z, Xiao X, Liu B, Chou KC (2016) iSuc-PseOpt: Identifying lysine succinylation sites in proteins by incorporating sequence-coupling effects into pseudo components and optimizing imbalanced training dataset. Anal Biochem 497: 48-56.

343. Chen W, Feng P, Yang H, Ding H, Lin H, et al. (2017) iRNA-AI: identifying the adenosine to inosine editing sites in RNA sequences. Oncotarget 8(3): 4208-4217.

344. Chen W, Ding H, Zhou X, Lin H, Chou KC (2018) iRNA(m6A)-PseDNC: Identifying N6-methyladenosine sites using pseudo dinucleotide composition. Analytical Biochemistry 561-562: 59-65.

345. Chen W, Feng P, Yang H, Ding H, Lin H, et al. (2018) iRNA-3typeA: identifying 3-types of modification at RNA's adenosine sites. Molecular Therapy: Nucleic Acid 11: 468-474.

346. Li JX, Wang SQ, Du QS, Wei H, Li XM, et al. (2018) Simulated protein thermal detection (SPTD) for enzyme thermostability study and an application example for pullulanase from Bacillus deramificans. Curr Pharm Des 24(34): 4023-4033.

347. Qiu WR, Sun BQ, Xiao X, Xu ZC, Jia JH, et al. (2018) iKcr-PseEns: Identify lysine crotonylation sites in histone proteins with pseudo components and ensemble classifier. Genomics 110(5): 239-246.

348. Chou KC (2019) Progresses in predicting post-translational modification. International Journal of Peptide Research and Therapeutics.

349. Du X, Diao Y, Liu H, Li S (2019) MsDBP: Exploring DNA-binding Proteins by Integrating Multi-scale Sequence Information via Chou's 5-steps Rule. Journal of Proteome Research 18(3): 3119-3132.

350. Ju Z, Wang SY (2019) Prediction of lysine formylation sites using the composition of k-spaced amino acid pairs via Chou's 5-steps rule and general pseudo components. Genomics. 
351. Khan YD, Batool A, Rasool N, Khan A, Chou KC (2019) Prediction of nitrosocysteine sites using position and composition variant features. Letters in Organic Chemistry 16: 283-293.

352. Le NQK (2019) iN6-methylat (5-step): identifying DNA N(6)methyladenine sites in rice genome using continuous bag of nucleobases via Chou's 5-step rule. Mol Genet Genomics 294(5): 11731182.

353. Le NQK, Yapp EKY, Ho QT, Nagasundaram N, Ou YY, et al. (2019) iEnhancer-5Step: Identifying enhancers using hidden information of DNA sequences via Chou's 5-step rule and word embedding. Anal Biochem 571: 53-61.

354. Lu Y, Wang S, Wang J, Zhou G, Zhang Q, et al. (2019) An Epidemic Avian Influenza Prediction Model Based on Google Trends. Letters in Organic Chemistry 16(4): 303-310.

355. Romero Molina S, Ruiz Blanco YB, Harms M, Münch J, Sanchez Garcia E (2019) PPI-Detect: A Support Vector Machine Model for Sequence-Based Prediction of Protein - Protein Interactions. Journal of Computational Chemistry 40(11): 1233-1242.

356. Salman M Khan, Iqbal N, Hussain T, Afzal S, Chou KC (2019) A twolevel computation model based on deep learning algorithm for identification of piRNA and their functions via Chou's 5-steps rule. International Journal of Peptide Research and Therapeutics (IJPRT).

357. Tahir M, Tayara H, Chong KT (2019) iDNA6mA (5-step rule): Identification of DNA N6-methyladenine sites in the rice genome by intelligent computational model via Chou's 5-step rule. CHEMOLAB 189: 96-101.

358. Song J, Li F, Takemoto K, Haffari G, Akutsu T, et al. (2018) PREvaIL, an integrative approach for inferring catalytic residues using sequence, structural and network features in a machine learning framework Journal of Theoretical Biology 443: 125-137.

359. Chen Z, Liu X, Li F, Li C, Marquez Lago T, et al. (2018) Large-scale comparative assessment of computational predictors for lysine posttranslational modification sites. Brief in Bioinform.

360. Chen Z, Zhao PY, Li F, Leier A, Marquez Lago TT, et al. (2018) iFeature: a python package and web server for features extraction and selection from protein and peptide sequences. Bioinformatics 34(14): 2499 2502.

361. Li F, Li C, Marquez Lago TT, Leier A, Akutsu T, et al. (2018) Quokka: comprehensive tool for rapid and accurate prediction of kinase familyspecific phosphorylation sites in the human proteome. Bioinformatics 34(24): 4223-4231.

362. Li F, Wang Y, Li C, Marquez Lago TT, Leier A, et al. (2018) Twenty years of bioinformatics research for protease-specific substrate and cleavage site prediction: a comprehensive revisit and benchmarking of existing methods. Brief in Bioinform.

363. Song J, Li F, Leier A, Marquez Lago TT, Akutsu T, et al. (2018) PROSPERous: high-throughput prediction of substrate cleavage sites for 90 proteases with improved accuracy. Bioinformatics 34(4): 684687.

364. Song J, Wang Y, Li F, Akutsu T, Rawlings ND, et al. (2018) iProt-Sub: a comprehensive package for accurately mapping and predicting protease-specific substrates and cleavage sites. Brief in Bioinform 20(2): 638-658.

365. Wang J, Li J, Yang B, Xie R, Marquez Lago TT, et al. (2018) Bastion3: a two-layer approach for identifying type III secreted effectors using ensemble learning. Bioinformatics 35(12): 2017-2028.

366. Wang J, Yang B, Leier A, Marquez Lago TT, Hayashida M, et al. (2018) Bastion6: a bioinformatics approach for accurate prediction of type VI secreted effectors. Bioinformatics 34(15): 2546-2555.

367. Zhang S, Yang K, Lei Y, Song K (2018) iRSpot-DTS: Predict recombination spots by incorporating the dinucleotide-based spare-cross covariance information into Chou's pseudo components. Genomics 111(6): 17601770 .

368. Zhang Y, Xie R, Wang J, Leier A, Marquez Lago TT, et al. (2018) Computational analysis and prediction of lysine malonylation sites by exploiting informative features in an integrative machine-learning framework. Brief in Bioinform.

369. Zhai X, Chen M, Lu W (2018) Accelerated search for perovskite materials with higher Curie temperature based on the machine learning methods. Computational Materials Science 151: 41-48.

370. Chou kC, Forsen S (1980) Diffusion-controlled effects in reversible enzymatic fast reaction system: Critical spherical shell and proximity rate constants. Biophysical Chemistry 12: 255-263.

371. Chou KC, Forsen S (1980) Graphical rules for enzyme-catalyzed rate laws. Biochemical Journal 187(3): 829-835.

372. Chou KC, Forsen S, Zhou GQ (1980) Three schematic rules for deriving apparent rate constants. Chemica Scripta 16: 109-113.

373. Chou KC, Li TT, Forsen S (1980) The critical spherical shell in enzymatic fast reaction systems. Biophysical Chemistry 12(3-4): 265-269.

374. Li TT, Chou KC, Forsen S (1980) The flow of substrate molecules in fast enzyme-catalyzed reaction systems. Chemica Scripta 16: 192-196.

375. Chou KC, Carter RE, Forsen S (1981) A new graphical method for deriving rate equations for complicated mechanisms. Chemica Scripta 18: 82-86.

376. Chou KC, Chen NY, Forsen S (1981) The biological functions of lowfrequency phonons: 2. Cooperative effects. Chemica Scripta 18: 126132.

377. Chou KC, Forsen S (1981) Graphical rules of steady-state reaction systems. Canadian Journal of Chemistry 59(4): 737-755.

378. Chou KC (1983) Low-frequency vibrations of helical structures in protein molecules. Biochemical Journal 209(3): 573-580.

379. Chou KC (1983) Identification of low-frequency modes in protein molecules. Biochemical Journal 215(3): 465-469.

380. Zhou GP, Deng MH (1984) An extension of Chou's graphic rules for deriving enzyme kinetic equations to systems involving parallel reaction pathways. Biochemical Journal 222(1): 169-176.

381. Chou KC (1984) Biological functions of low-frequency vibrations (phonons). 3. Helical structures and microenvironment. Biophysical Journal 45(5): 881-889.

382. Chou KC (1984) The biological functions of low-frequency phonons. 4. Resonance effects and allosteric transition. Biophysical Chemistry 20: $61-71$

383. Chou KC (1984) Low-frequency vibrations of DNA molecules. Biochemical Journal 221(1): 27-31.

384. Chou KC (1985) Low-frequency motions in protein molecules: betasheet and beta-barrel. Biophysical Journal 48(2): 289-297.

385. Chou KC (1985) Prediction of a low-frequency mode in bovine pancreatic trypsin inhibitor molecule. International Journal of Biological Macromolecules 7(2): 77-80.

386. Chou KC, Kiang YS (1985) The biological functions of low-frequency phonons: 5. A phenomenological theory. Biophysical Chemistry 22(3): 219-235.

387. Chou KC (1986) Origin of low-frequency motion in biological macromolecules: A view of recent progress of quasi-continuity model. Biophysical Chemistry 25(2):105-116.

388. Chou KC (1987) The biological functions of low-frequency phonons: 6. A possible dynamic mechanism of allosteric transition in antibody molecules. Biopolymers 26: 285-295. 
389. Chou KC (1988) Review: Low-frequency collective motion in biomacromolecules and its biological functions. Biophysical Chemistry 30(1): 3-48.

390. Chou KC, Maggiora GM (1988) The biological functions of lowfrequency phonons: 7. The impetus for DNA to accommodate intercalators. British Polymer Journal 20: 143-148.

391. Chou KC (1989) Low-frequency resonance and cooperativity of hemoglobin. Trends in Biochemical Sciences 14(6): 212-213.

392. Chou KC, Maggiora GM, Mao B (1989) Quasi-continuum models of twist-like and accordion-like low-frequency motions in DNA. Biophysical Journal 56(2): 295-305.

393. Chou KC (1989) Graphic rules in steady and non-steady enzyme kinetics. Journal of Biological Chemistry 264(20): 12074-12079.

394. Chou KC (1990) Review: Applications of graph theory to enzyme kinetics and protein folding kinetics. Steady and non-steady state systems. Biophysical Chemistry 35(1): 1-24.

395. Althaus IW, Chou JJ, Gonzales AJ, Diebel MR, Chou KC, et al. (1993) Steady-state kinetic studies with the non-nucleoside HIV-1 reverse transcriptase inhibitor U-87201E. Journal of Biological Chemistry 268(9): 6119-6124.

396. Althaus IW, Gonzales AJ, Chou JJ, Diebel MR, Chou KC, et al. (1993) The quinoline U-78036 is a potent inhibitor of HIV-1 reverse transcriptase. Journal of Biological Chemistry 268(20): 14875-14880.

397. Althaus IW, Chou JJ, Gonzales AJ, Diebel MR, Chou KC, et al. (1993) Kinetic studies with the nonnucleoside HIV-1 reverse transcriptase inhibitor U-88204E. Biochemistry 32(26): 6548-6554.

398. Althaus IW, Chou JJ, Gonzales AJ, Diebel MR, Chou KC, et al. (1994) Steady-state kinetic studies with the polysulfonate U-9843, an HIV reverse transcriptase inhibitor. Cellular and Molecular Life Science (Experientia) 50(1): 23-28.

399. Althaus IW, Chou JJ, Gonzales AJ, Diebel MR, Chou KC, et al. (1994) Kinetic studies with the non-nucleoside human immunodeficiency virus type-1 reverse transcriptase inhibitor U-90152e. Biochemical Pharmacology 47(11): 2017-2028.

400. Chou KC, Kezdy FJ, Reusser F (1994) Review: Kinetics of processive nucleic acid polymerases and nucleases. Analytical Biochemistry 221(2): 217-230.

401. Chou KC, Zhang CT, Maggiora GM (1994) Solitary wave dynamics as a mechanism for explaining the internal motion during microtubule growth. Biopolymers 34: 143-153.

402. Althaus IW, Chou KC, Franks KM, Diebel MR, Kezdy FJ, et al. (1996) The benzylthio-pyrididine U-31,355, a potent inhibitor of HIV-1 reverse transcriptase. Biochemical Pharmacology 51(6): 743-750.

403. Liu H, Wang M, Chou KC (2005) Low-frequency Fourier spectrum for predicting membrane protein types. Biochem Biophys Res Commun (BBRC) 336: 737-739.

404. Gordon G (2007) Designed Electromagnetic Pulsed Therapy: Clinical Applications. Journal of Cellular Physiology 212: 579-582.

405. Andraos J (2008) Kinetic plasticity and the determination of product ratios for kinetic schemes leading to multiple products without rate laws: new methods based on directed graphs. Canadian Journal of Chemistry 86: 342-357.

406. Chou KC, Shen HB (2009) FoldRate: A web-server for predicting protein folding rates from primary sequence. The Open Bioinformatics Journal 3: 31-50.

407. Shen HB, Song JN, Chou KC (2009) Prediction of protein folding rates from primary sequence by fusing multiple sequential features Journal of Biomedical Science and Engineering (JBiSE) 2(3): 136-143.
408. Wang JF, Chou KC (2009) Insight into the molecular switch mechanism of human Rab5a from molecular dynamics simulations. Biochem Biophys Res Commun (BBRC) 390: 608-612.

409. Gordon G (2008) Extrinsic electromagnetic fields, low frequency (phonon) vibrations, and control of cell function: a non-linear resonance system. Journal of Biomedical Science and Engineering (JBiSE) 1: 152-156.

410. Madkan A, Blank M, Elson E, Chou KC, Geddis MS, et al. (2009) Steps to the clinic with ELF EMF. Natural Science 1: 157-165.

411. Chou KC (2010) Graphic rule for drug metabolism systems. Current Drug Metabolism 11(4): 369-378.

412. Chou KC, Lin WZ, Xiao X (2011) Wenxiang: a web-server for drawing wenxiang diagrams. Natural Science 3: 862-865.

413. Lian P, Wei DQ Wang JF, Chou KC (2011) An allosteric mechanism inferred from molecular dynamics simulations on phospholamban pentamer in lipid membranes. PLoS ONE 6(4): e18587.

414. Liao QH, Gao QZ, Wei J, Chou KC (2011) Docking and Molecular Dynamics Study on the Inhibitory Activity of Novel Inhibitors on Epidermal Growth Factor Receptor (EGFR). Medicinal Chemistry 7(1): 24-31.

415. Li J, Wei DQ, Wang JF, Yu ZT, Chou KC (2012) Molecular Dynamics Simulations of CYP2E1. Medicinal Chemistry 8: 208-221.

416. Wang JF, Chou KC (2012) Recent advances in computational studies on influenza a virus $\mathrm{m} 2$ proton channel. Mini Reviews in Medicinal Chemistry 12: 971-978.

417. Zhang T, Wei DQ, Chou KC (2012) A Pharmacophore Model Specific to Active Site of CYP1A2 with a Novel Molecular Modeling Explorer and CoMFA. Medicinal Chemistry 8: 198-207.

418. Chou KC (2019) Proposing pseudo amino acid components is an important milestone for proteome and genome analyses. International Journal for Peptide Research and Therapeutics (IJPRT).

419. Chou KC (2019) Artificial intelligence (AI) tools constructed via the 5 -steps rule for predicting post-translational modifications. Trends in Artificial Inttelengence (TIA) 3: 60-74.

420. Chou KC (2019) Impacts of pseudo amino acid components and 5 -steps rule to proteomics and proteome analysis. Current Topics in Medicinak Chemistry (CTMC) 19(5).

421. Chou KC (2019) An insightful 10-year recollection since the emergence of the 5-steps rule. Current Pharmaceutical Design (Special Issue ed. Bing Nui) in press.

422. Chou KC (2019) An insightful 20-year recollection since the birth of pseudo amino acid components. Computers in Biology and Medicine in press.

423. Chou KC (2019) An insightful recollection for predicting protein subcellular locations in multi-label systems. Genomics.

424. Chou KC (2019) An insightful recollection since the distorted key theory was born about 23 years ago. Genomics.

425. Chou KC (2019) Recent progresses in predicting protein subcellular localization with artificial intelligence tools developed via the 5-steps rule. Medicinal Chemistry Submitted.

426. Chou KC (2019) Two kinds of metrics for computational biology. Genomics.

427. Chou KC (2020) Distorted Key Theory and Its Implication for Drug Development. Current Genomics. 
ISSN: 2574-1241

DOI: 10.26717/BJSTR.2019.23.003978

Kuo Chen Chou. Biomed J Sci \& Tech Res

(c) (P) This work is licensed under Creative

Submission Link: https://biomedres.us/submit-manuscript.php

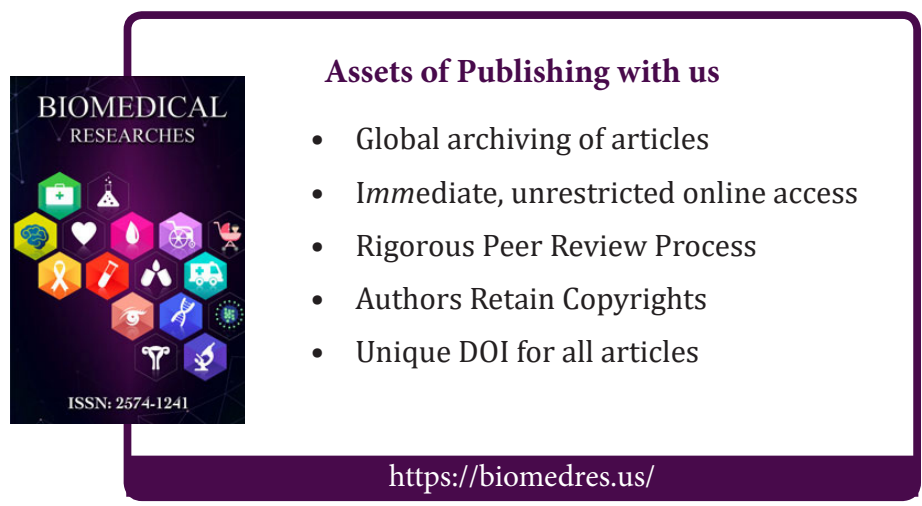

